\title{
Three new species of Byrsopteryx Flint microcaddisflies from Peru (Insecta: Trichoptera) including DNA-based larval associations
}

\author{
Allan PM Santos ${ }^{\text {Corresp., } 1}$, Daniela Maeda Takiya ${ }^{2}$ \\ 1 Departamento de Zoologia, Universidade Federal do Estado do Rio de Janeiro, Rio de Janeiro, Rio de Janeiro, Brazil \\ 2 Departamento de Zoologia, Universidade Federal do Rio de Janeiro, Rio de Janeiro, Rio de Janeiro, Brazil \\ Corresponding Author: Allan PM Santos \\ Email address: allanpms@gmail.com
}

In this paper, we have described and illustrated three new species of Byrsopteryx from Peru: Byrsopteryx inti sp. nov., Byrsopteryx mamaocllo sp. nov., and Byrsopteryx mancocapac sp. nov. Larvae of the latter two were also associated to male specimens based on comparison of a fragment of $\mathrm{COI}$ gene and pharate male identification. Byrsopteryx inti sp. nov. and Byrsopteryx mamaocllo sp. nov. share a unique feature: a semi-dome process formed by a thickened area on male forewings. The three species can be easily identified by wing coloration and male genitalia. Furthermore, Byrsopteryx inti sp. nov. can be recognized by its sternum VIII with a median digitate process on posterior margin, slightly capitate; and by long dorsolateral processes from segment VIII, which cross each other apically in dorsal view. Byrsopteryx mamaocllo sp. nov. can be distinguished by sternum VIII bearing a pair of short, posterior, spinelike processes, which are curved inwards and bordered by a rounded, membranous structure, and by a pair of short, heavily sclerotized, dorsolateral processes. Byrsopteryx mancocapac sp. nov. can be distinguished by strong spine-like processes arising dorsally from subgenital plate and by sternum VIII with posterior margin divided into two plate-like lobes. Larvae of $B$. mamaocllo sp. nov. and B. mancocapac sp. nov. are similar to other Byrsopteryx larvae known. They can be distinguished from each other by the shape of the operculum formed by terga VIII and IX, and number of setae on the second abdominal pleurite. Maximum likelihood analyses of $20 \mathrm{COI}$ sequences, including nine Byrsopteryx species, placed $B$. inti sp. nov. and $B$. mamaocllo sp. nov. as sister species and related to a clade including $B$. gomezi, $B$. tapanti, and $B$. esparta, while $B$. mancocapac sp. nov. was found as sister to $B$. abrelata. Despite the close phylogenetic relationship found between $B$. inti sp. nov. and $B$. mamaocllo sp. nov., they are separated by $14.9 \%$ minimum K2P divergence of COI. The highest intraspecific distance observed was $1.4 \%$ for $B$. mancocapac sp. nov. individuals. Although the Peruvian caddisfly fauna has around 320 known species and almost a third of 
them are microcaddisflies, in this paper we present the first descriptions of Byrsopteryx species for the country. 


\section{Three new species of Byrsopteryx Flint}

2 microcaddisflies from Peru (Insecta: Trichoptera)

3 including DNA-based larval associations

4

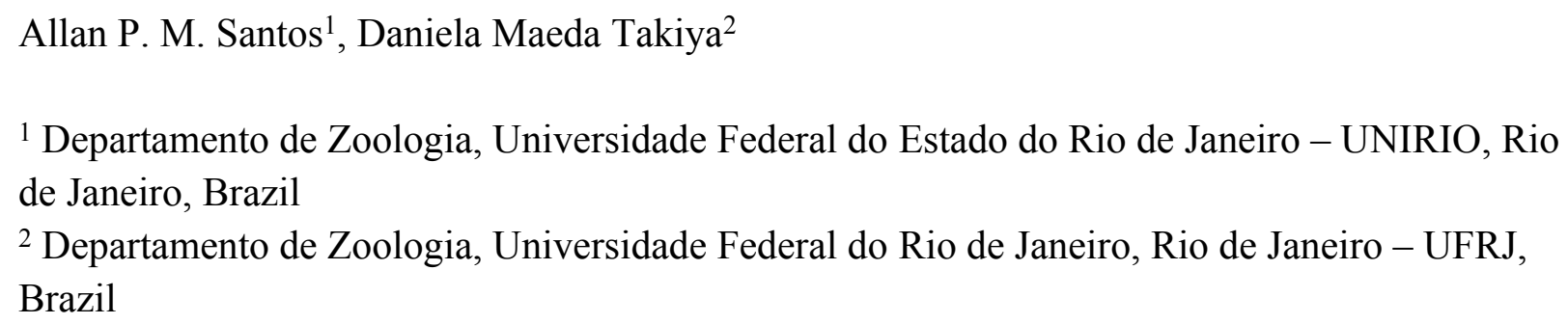

\section{Abstract}

In this paper, we have described and illustrated three new species of Byrsopteryx from Peru: Byrsopteryx inti sp. nov., Byrsopteryx mamaocllo sp. nov., and Byrsopteryx mancocapac sp. nov.. Larvae of the latter two were also associated to male specimens based on comparison of a fragment of COI gene and pharate male identification. Byrsopteryx inti sp. nov. and Byrsopteryx mamaocllo sp. nov. share a unique feature: a semi-dome process formed by a thickened area on male forewings. The three species can be easily identified by wing coloration and male genitalia. Furthermore, Byrsopteryx inti sp. nov. can be recognized by its sternum VIII with a median digitate process on posterior margin, slightly capitate; and by long dorsolateral processes from segment VIII, which cross each other apically in dorsal view. Byrsopteryx mamaocllo sp. nov. can be distinguished by sternum VIII bearing a pair of short, posterior, spinelike processes, which are curved inwards and bordered by a rounded, membranous structure, and by a pair of short, heavily sclerotized, dorsolateral processes. Byrsopteryx mancocapac sp. nov. can be distinguished by strong spine-like processes arising dorsally from subgenital plate and by sternum VIII with posterior margin divided into two plate-like lobes. Larvae of B. mamaocllo sp. nov. and B. mancocapac sp. nov. are similar to other Byrsopteryx larvae known. They can be distinguished from each other by the shape of the operculum formed by terga VIII and IX, and number of setae on the second abdominal pleurite. Maximum likelihood analyses of $20 \mathrm{COI}$ sequences, including nine Byrsopteryx species, placed $B$. inti sp. nov. and B. mamaocllo sp. nov. as sister species and related to a clade including $B$. gomezi, B. tapanti, and B. esparta, while $B$. mancocapac sp. nov. was found as sister to $B$. abrelata. Despite the close phylogenetic relationship found between $B$. inti sp. nov. and $B$. mamaocllo sp. nov., they are separated by $14.9 \%$ minimum K2P divergence of COI. The highest intraspecific distance observed was $1.4 \%$ 
40 for B. mancocapac sp. nov. individuals. Although the Peruvian caddisfly fauna has around 320

41 known species and almost a third of them are microcaddisflies, in this paper we present the first 42 descriptions of Byrsopteryx species for the country.

43

44

45

46

47

48

49

50

51

52

53

54

55

56

57

58

59

60

61

62

63

64

65

66

67

68

69

70

71

72

73

74

75

76

77

78

79

\section{Introduction}

Hydroptilidae, or microcaddisflies, constitute the most diverse family in the order Trichoptera, with over 2,500 named species in 74 genera (Morse et al., 2019). Microcaddisflies are recorded from all zoogeographic regions, except Antarctic, and are particularly diverse in the Neotropics, where almost a thousand species are currently known (Holzenthal \& Calor, 2017, Morse et al., 2019). Despite their diversity, microcaddisflies are usually neglected by taxonomists due to their small body size (usually less than $5.0 \mathrm{~mm}$ ), which makes difficult to manipulate specimens and to observe morphological features.

Current family classification derives mostly from the comprehensive revision provided by Marshall (1979), including 46 genera known at the time. Six subfamilies are recognized in Hydroptilidae, defined as tribes by Marshall (1979), all of them recorded from the Neotropics (Holzenthal \& Calor, 2017). Leucotrichiinae are restricted to the New World, with most species recorded from the Neotropical Region. The subfamily delimitation has been revised by Santos, Nessimian \& Takiya (2016) based on a phylogenetic hypothesis, and now it includes two tribes: Alisotrichiini and Leucotrichiini, with respectively six and ten genera. Byrsopteryx Flint, 1981 belongs to the Alisotrichiini and its monophyly has been consistently supported by morphological and molecular data (Harris \& Holzenthal, 1994; Santos, Nessimian \& Takiya, 2016).

Among Neotropical microcaddisflies, adults of Byrsopteryx are easily recognized by their coloration, with white spots over a black background (Harris \& Holzenthal, 1994; Santos \& Nessimian, 2010). While adult caddisflies are usually collected at night with light traps, adults of Byrsopteryx are more active during the day, and rarely flies to nocturnal traps. They also differ from most caddisfly species due to their behavior, under bright sunlight, adults of Byrsopteryx can be seen running fast over rocks or large leaves of riparian vegetation in a zigzag or in a more erratic way (Flint, 1981; Harris \& Holzenthal, 1994; Santos \& Nessimian, 2010). They intercalate frantic running with moments when they seem frozen in a position or when they start to revolve around the axis of their own heads (Flint, 1981; Harris \& Holzenthal, 1994; Santos \& Nessimian, 2010). When disturbed, they just fly off to find another place and start these movements again. Thus, adults of Byrsopteryx are more easily collected with aspirators or directly with a finger moistened in alcohol. They occasionally come to light and Malaise traps, but in relatively low numbers, especially compared to other Neotropical caddisflies.

Byrsopteryx larvae build purse-like portable cases, like those built by Celaenotrichia Mosely, 1934 larvae, another genus of Alisotrichiini. Larval case is weakly sealed dorsally, made mainly of silk and usually with mineral grains and/or algae filaments added (Holzenthal \& Harris, 1991; Santos \& Nessimian, 2010). Larvae are typically madicolous, being found in waterfalls, living in the spray and splash zone or in small streams on boulders (Holzenthal \& Harris, 1991; Harris \& 
80

81

82

83

84

85

86

87

88

89

90

91

92

93

94

95

96

97

98

99

100

101

102

103

104

105

106

107

108

109

110

111

112

113

114

115

116

117

118

119

Holzenthal, 1994; Santos \& Nessimian, 2010). They seem to feed mainly on diatoms, which they apparently scrape from the substrate along with associated periphyton (Holzenthal \& Harris, 1991; Santos \& Nessimian, 2010). Pupae are fixed to the rocky substrate by a short peduncle, and are commonly found in aggregation above the waterline in pits or small depressions (Holzenthal \& Harris, 1991; Santos \& Nessimian, 2010).

Currently, 16 species are assigned to Byrsopteryx and they occur from southern Mexico; in Central America, including the Caribbean; through northwestern and southeastern South America (Holzenthal \& Calor, 2017). Larvae of four species are currently known: B. abrelata Harris \& Holzenthal, 1994, B. carioca Santos \& Nessimian, 2010, and B. espinhosa Harris \& Holzenthal, 1994 from Brazil (Santos \& Nessimian, 2010), and B. mirifica Flint, 1981 from Venezuela (Flint, 1981; Holzenthal \& Harris, 1991). Just recently, typical larvae of Byrsopteryx were recorded from Colombia (Vásquez-Ramos, Osorio-Ramírez \& Caro-Caro, 2020). Santos, Nessimian \& Takiya (2016) listed three undetermined Byrsopteryx species from Peru among the examined material used in for phylogenetic analyses, but no species of Byrsopteryx is recorded from the country so far. Peru has a highly diverse fauna of caddisflies, with around 320 known species, almost a third of them being microcaddisflies (Holzenthal \& Calor, 2017). Important works on this fauna include those of Flint $(1975,1980,1996)$ and Flint \& Reyes (1991), and those focusing on hydroptilids of Flint \& Bueno-Soria $(1998,1999)$ and Harris \& Davenport $(1992,1999)$. However, many new species of caddisflies from Peru remain in collections to be described, indicating that this fauna is still very underworked. Here we describe three new species of Byrsopteryx from Peru, including larval descriptions for two of them. Larval associations for these species are based on comparison of a fragment of the mitochondrial gene cytochrome oxidase I (COI) from males and larvae and also, for one of them, comparison among cases and structures of pharate males and larvae.

\section{Materials \& Methods}

\section{Specimen collecting and morphological study}

Adults and immatures of Byrsopteryx studied here were collected with aspirators, with finger moistened in alcohol (adults) or with aid of entomological forceps (immatures). In addition, adults were also collected with a Malaise trap set at one of the collecting sites. Specimens were collected under permit RD-0297-2012-AG-DGFFS-DGEFFS, issued by Dirección General Forestal y de Fauna Silvestre, Peru. Larvae and most adults were fixed and preserved in 96\% ethanol, however some adults were killed in jars with ethyl acetate and pinned dry, to better preserve coloration. Byrsopteryx specimens were found in four sites, in Cusco and Puno provinces, Peru. Collecting sites exhibited the typical environment for Byrsopteryx species: rocky streams and small waterfalls (Fig. 1).

Male and female genital structures were analyzed after the clearing procedure with a heated solution of $10 \% \mathrm{KOH}$, as described in Ross (1994). Abdomens were mounted in temporary slides and observed under a compound microscope equipped with camera lucida. Then, pencil sketches were made and used as templates in Adobe Illustrator (Adobe Systems Inc.) to create 
120

121

122

123

124

125

126

127

128

129

130

131

132

133

134

135

136

137

138

139

140

141

142

143

144

145

146

147

148

149

150

151

152

153

154

155

156

157

158

159

vector graphics, as detailed in Holzenthal (2008). Adult male holotypes and larvae were photographed with a digital camera attached to a Leica stereomicroscope. Photographs at different focal planes were obtained and then stacked with Leica Application Suite or Helicon focus Lite software and then edited in Adobe Photoshop (Adobe Systems Inc.). After observation, abdomens were stored in microvials with ethanol, for specimens in alcohol, or glycerin for pinned specimens. Terminology used here follows that of Harris \& Holzenthal (1994), except for the inferior appendages, for which we used the interpretation of Santos, Nessimian \& Takiya (2016). Holotypes of the newly described species are deposited at Museo de Historia Natural, Universidad Nacional Mayor de San Marcos, Lima (MUSM). Paratypes are in the same institution and also in Coleção Prof. José Alfredo Pinheiro Dutra, Departamento de Zoologia, Universidade Federal do Rio de Janeiro, Rio de Janeiro (DZRJ) and Coleção de Invertebrados, Instituto Nacional de Pesquisas da Amazônia, Manaus (INPA). Extracted DNA solutions are deposited at DZRJ.

\section{DNA extraction, amplification, and sequencing}

DNA was extracted from the entire body of specimens using the Wizard SV Genomic DNA Purification System (Promega Corporation, Madison, USA), without tissue maceration. After extraction, specimens were returned to ethanol and deposited in the original collection as a DNA voucher. COI fragments were amplified using different pair of primers (Folmer et al., 1994; Simon et al., 1994): HCO-2198 (5'-TAAACTTCAGGGTGACCAAAAAATCA) in combination with LCO- 1490 (5'-GGTCAACAAATCATAAAGATATTGG); HCO-2198 with C1-J-1718 (5'-GGAGGATTTGGAAATTGATTAGTTCC); or Ron (5'-

\section{GGATCACCTGATATAGCATTCCC) and Nancy (5'-} CCCGGTAAAATTAAAATATAAACTTC).

Polymerase chain reaction (PCR) conditions were as follows: when using HCO-2198 and LCO-1490, initial denaturation at $95^{\circ} \mathrm{C}$ for $3 \mathrm{~min} ; 5$ cycles of denaturation at $95{ }^{\circ} \mathrm{C}$ for $1 \mathrm{~min}$, annealing at $45^{\circ} \mathrm{C}$ for $1,5 \mathrm{~min}$, and extension at $72^{\circ} \mathrm{C}$ for $1 \mathrm{~min}$, then 35 cycles of $95{ }^{\circ} \mathrm{C}$ for 40 $\mathrm{s}, 51^{\circ} \mathrm{C}$ for $1 \mathrm{~min}$, and $72{ }^{\circ} \mathrm{C}$ for $1 \mathrm{~min}$; and final extension at $72{ }^{\circ} \mathrm{C}$ for $7 \mathrm{~min}$. When using other primer combinations, initial denaturation at $94{ }^{\circ} \mathrm{C}$ for $3 \mathrm{~min}$; then 35 cycles of $94{ }^{\circ} \mathrm{C}$ for $1 \mathrm{~min}$, $50{ }^{\circ} \mathrm{C}$ for $1 \mathrm{~min}$, and $72{ }^{\circ} \mathrm{C}$ for $2 \mathrm{~min}$; and final extension at $72{ }^{\circ} \mathrm{C}$ for $7 \mathrm{~min}$. PCR products were sent to Macrogen Inc., Seoul, for purification and sequencing reactions.

\section{Phylogenetic analysis}

Forward and reverse electropherograms of each sample were assembled and manually edited in Sequencher 4.1 (Gene Codes, Ann Arbor, Michigan, USA). Consensus sequences were verified with the Blast tool in GenBank to check for contamination. Additional sequences of Byrsopteryx and of Celaenotrichia edwardsi Mosely, 1934 as outgroup, were obtained from Bold Systems (Table 1). COI sequences were aligned using ClustalW algorithm implemented in MEGA X (Kumar et al., 2018) and translated into amino-acid sequences to check for stop codons. Final alignment resulted in a matrix with 653 bp and 20 sequences (Supplementary File 
160 1). All COI sequences are available in GenBank (accession numbers are provided in Table 1).

161

162

163

164

165

166

167

168

169

170

171

172

173

174

175

176

177

178

179

180

181

182

183

184

185

186

187

188

189

190

191

192

193

194

195

196

197

198

199

MEGA X was also used to Kimura 2-Parameter (K2P) divergences (Kimura, 1980), with pairwise deletion of missing information. A maximum likelihood analysis was conducted in RAxML 8.2.11 (Stamatakis, 2014) with 500 search replicates and model $\mathrm{GTR}+\mathrm{G}+\mathrm{I}$, as selected in jModeltest 2 (Darriba et al., 2012) using Akaike Information Criterion (Akaike, 1974). Branch support tree was assessed with 1,000 pseudoreplicates of non-parametric bootstrap (BS, Felsenstein, 1985).

\section{New species names}

The electronic version of this article in Portable Document Format (PDF) will represent a published work according to the International Commission on Zoological Nomenclature (ICZN), and hence the new names contained in the electronic version are effectively published under that Code from the electronic edition alone. This published work and the nomenclatural acts it contains have been registered in ZooBank, the online registration system for the ICZN. The ZooBank LSIDs (Life Science Identifiers) can be resolved and the associated information viewed through any standard web browser by appending the LSID to the prefix http://zoobank.org/. The LSID for this publication is: urn:lsid:zoobank.org:pub:71531CB9-F919-4DB9-8885-

B8207F0A82F4. The online version of this work is archived and available from the following digital repositories: PeerJ, PubMed Central and CLOCKSS.

\section{Results}

\section{Phylogenetic analysis and species divergences}

The maximum likelihood tree $(-\operatorname{lnL}=3322.784548$, Fig. 2$)$ recovered two of the new species described herein, $B$. inti sp. nov. and B. mamaocllo sp. nov., as sister species $(B S=79)$ and related to a clade (BS=52) including B. gomezi, $B$. tapanti, and B. esparta. The other new species described, $B$. mancocapac sp. nov., was found as sister to $B$. abrelata, but with no significant bootstrap support.

Concerning species interspecific COI K2P divergences, Byrsopteryx species varied from 12.3-26.1\% (see Supplementary Table 1), minimum divergence (K2P distances) was between $B$. tapanti and B. gomezi, both from Costa Rica. Among the Peruvian species, minimum interspecific divergence was $14.9 \%$, between $B$. inti sp. nov. and B. mamaocllo sp. nov.. Furthermore, maximum K2P intraspecific distances observed were $1.4 \%$ for $B$. mancocapac sp. nov. $(\mathrm{n}=8), 0.7 \%$ for B. mamaocllo sp. nov. $(\mathrm{n}=3)$, and $0 \%$ for $B$. gomezi $(\mathrm{n}=2)$. Based on these divergences and phylogenetic placement (Fig. 2), we were able to associate males and larval specimens of $B$. mamaocllo sp. nov. and B. mancocapac sp. nov.

\section{Taxonomy}

Byrsopteryx inti new species

urn:1sid:zoobank.org:act:9B5FAC2D-A98F-4B88-97BC-CE7CA5105535

- Byrsopteryx sp. PE1 Santos, Nessimian \& Takiya, 2016:461. Phylogenetic placement.

Peer) reviewing PDF | (2021:09:66094:1:1:NEW 22 Nov 2021) 
200 Figs. 3-5

201 Description. Adult male. Coloration. General color dark brown; head dorsum and antennal base 202 densely covered with white setae; mesoscutum mostly covered with white setae; forewing with 203 four distinct maculae of white setae: an oval band at base of medial area, a trapezoidal macula 204 near midcostal margin, a small subapical spot near posterior margin of wing, and an apical spot 205 (Fig. 3). Length. Total length 2.4-2.6 mm (n=3). Head. Unmodified. Antennae 19-articulated. 206 Ocelli 3. Maxillary palpi 5-articulated; articles I and II very short and globular, article III very 207 long, as long as articles IV and V combined; articles IV and V with similar lengths, each one 208 about twice as long as wide. Thorax. Forewing venation strongly reduced; with small, oblique 209 basal lobe; line of weakness distinct, bordered by row of very long, thin setae; with semi-dome 210 formed by a thickening of wing membrane, to which apices of very long setae converge; 211 retinaculum distinct (Fig. 4a). Hind wing venation reduced; frenulum distinct, with row of four 212 short, hooked setae (Fig. 4b). Tibial spur formula 0, 3, 4. Abdomen. Segment VII without 213 ventromesal process. Male genitalia. Segment VIII shorter dorsally than ventrally. Sternum with 214 median digitate process posteriorly, slightly capitate (Fig. 5a); with pair of posteroventral 215 processes, diverging apically in ventral view (Fig. 5a), slightly upturned in lateral view, each one 216 with a thin rounded membrane at apex (Figs. 5b, 5d); and with pair of dorsolateral processes, 217 crossing each other apically in dorsal view (Fig. 5c), upturned in lateral view (Fig. 5d). Very 218 long stout setae covering apical portions of both sternum and tergum. Segment IX recessed 219 within segment VIII, projecting anteriorly through posterior portion of segment VII; open 220 ventrally; with deep mesal incision anteriorly in dorsal and ventral views (Figs. 5a, 5c); 221 narrowing anteriorly in lateral view (Fig. 5d). Subgenital plate slender, with rounded apex in 222 ventral view (Fig. 5a), downturned and with apical semicircular incision (Fig. 5d). Inferior 223 appendages positioned dorsolaterally; elongate, digitate, converging apically in ventral and 224 dorsal view (Figs. 5a, 5c); downturned in lateral view (Fig. 5d); covered with very short setae.

225 Tergum X membranous; covered with minute setae; with sclerotized lateral bars. Phallus tubular, 226 with slight constriction between basal and apical portions; basal portion short, about half length 227 of apical portion and slightly wider; sclerotized region of apex with deep median incision in 228 dorsal view, with pair of short triangular projections at basal margin of the incision (Fig. 5e), 229 with a V-shaped incision in lateral view (Fig. 5f); membranous at apex.

230 Adult female. Unknown.

231 Larva. Unknown.

232 Type material. Holotype male. PERU: Cusco, 19 rd km W Quincemil, Río Araza tributary. 233 13²0'10'S 7050'57'W 874 m. 23-28.viii.2012. Malaise trap. RR Cavichioli, JA Rafael, APM 234 Santos, DM Takiya leg. Alcohol (MUSM). Paratypes. Same data as holotype, except 1 male, 235 pinned (DZRJ); same data as holotype, manual collecting, 2 males, in alcohol (MUSM), 1 male, 236 in alcohol (DZRJ).

237 Etymology. The species name (used as a noun in apposition) is an allusion to the popular Inca 238 god Apu Inti, the sun god. The Inca people appeared in the Andes region and established the Inca 
239 Empire in pre-Colombian America. Cusco, where the type material comes from, was the center

240 of the Inca Empire.

241 Distribution. Peru (Cusco).

242 Remarks. Among the three new species described here from Peru, Byrsopteryx inti sp. nov. was

243 the most rarely collected. Only five male specimens were collected and, although Byrsopteryx

244 larvae and adults were abundantly seen and collected in explored localities, both female and

245 immature specimens of this new species were not found and remain unknown.

246 Males of $B$. inti sp. nov. share with those of B. mamaocllo sp. nov. a feature not observed

247

248

249

250

251

252

253

254

255

256

257

258

259

260

261

262

263

264

265

266

267

268

269

270

271

272

273

274

275

276

277

278 in any other species in the genus: presence of a sclerotized semi-dome on forewings (Figs. 3a, 4a). Also, the general aspect of the male genitalia of these two new species is also most similar (Figs. 5b, 5d, 8b, 8d), in that they share both a pair of dorsolateral and a pair of posteroventral processes on sternum VIII. Other Byrsopteryx species that also have dorsolateral processes on segment VIII are B. chaconi Harris \& Holzenthal, 1994, B. cuchilla Harris \& Holzenthal, 1994, B. esparta Harris \& Holzenthal, 1994, B. solisi Harris \& Holzenthal, 1994, B. tapanti Harris \& Holzenthal, 1994, and B. tica Harris \& Holzenthal, 1994. However, B. inti sp. nov. can be further distinguished from all others based on (1) the sternum VIII with a median digitate process, slightly capitate posteriorly (Fig. 5a); and (2) longer dorsolateral processes from segment VIII, which cross each other apically in dorsal view (Fig. 5c).

\section{Byrsopteryx mamaocllo new species}

urn:lsid:zoobank.org:act:2F8A72D9-FE9C-4C82-BFA4-26238FBEEBB7

- Byrsopteryx sp. PE2 Santos, Nessimian \& Takiya, 2016:461. Phylogenetic placement. Figs. 6-10

Description. Adult male. Coloration. General color dark brown; head dorsum and antennal base densely covered with white setae; mesoscutum mostly covered with white setae; forewing with three maculae of white setae, a longitudinal band along basal third of costal margin, a subapical spot near posterior margin of wing, and an apical spot (Fig. 6). Length. Total length 2.6-3.0 mm $(\mathrm{n}=15)$. Head. Unmodified. Antennae 20-articulated. Ocelli 3. Maxillary palpi 5-articulated; articles I and II very short and globular, article III very long, as long as articles IV and V combined; articles IV and V with similar lengths, each one about twice as long as wide. Thorax. Forewing venation strongly reduced; with small, oblique basal lobe; line of weakness distinct, bordered by row of very long, thin setae; with semi-dome formed by thickening of wing membrane (absent in females), to which apices of very long setae converge; retinaculum distinct (Fig. 7a). Hind wing venation reduced; frenulum distinct, with row of five short, hooked setae (Fig. 7b). Tibial spur formula 0, 3, 4. Abdomen. Segment VII without ventromesal process. Male genitalia. Segment VIII shorter dorsally than ventrally. Sternum with a pair of short spinelike posteroventral processes, curved inwards in ventral and caudal views (Figs. 8a, 8b), upturned in lateral view (Fig. 8d), each one with a thin rounded membrane; and with pair of short dorsolateral digitate processes, slightly upturned in lateral view (Fig. 8d). Very long stout setae covering apical portions of both sternum and tergum. Segment IX recessed within segment VIII, 
279 projecting anteriorly through posterior portion of segment VII; with deep mesal incision 280 anteriorly in ventral and dorsal views (Figs. 8a, 8c); narrowing anteriorly in lateral view (Fig. 281 8d). Subgenital plate subtriangular in ventral and dorsal views, apex with a small darkened 282 digitate projection (Figs. 8a, 8c); apex downturned in lateral view (Fig. 8d). Inferior appendages 283 positioned dorsolaterally; elongate, almost straight, parallel in dorsal and ventral views (Figs. 8a, 284 8c); apex downturned in lateral view (Fig. 8d); covered with very short setae. Tergum $X$ 285 membranous; covered with minute setae or sensilla; with sclerotized lateral bars. Phallus tubular; 286 with slight constriction between basal and apical portions; basal portion short, about half length 287 of apical portion; sclerotized region of apex rounded in dorsal view, with a short bifid projection 288 subapically in dorsal view (Fig. 8e), trifid in lateral view (Fig. 8f); membranous at apex. 289 Adult female. Coloration and general morphology of head and thorax as in male, except 290 forewing simple, without semi-dome structure or any other modification. Length. Total length 291 292 293 294 ventrally with short plumose setae (Fig. 9a). Segment VIII approximately as long as wide, with row of long setae on posterior margin, internally with pair of elongate lateral apodemes extending to middle of segment VII (Fig. 9a). Segment IX short, slightly sclerotized, internally with pair of elongate lateral apodemes extending to anterior margin of segment VIII (Fig. 9a). Segment X very short, narrowed apically, with a pair of digitate papillae (Fig. 9a). Vaginal apparatus slightly sclerotized, inconspicuous in cleared specimens; elongate, with anterior region rounded (Fig. 9b).

Larva (final instar). Length 1.8-2.5 mm (n=29). Head brown to dark brown, unpigmented around eyes; quadrangular; frontoclypeal and coronal sutures indistinct; dorsum with reticulate pattern formed by microscopic setae; setae 9 very long; antennae 1-articulated, apical seta indistinct; mandibles without distinct teeth. Thoracic nota strongly sclerotized, brown, with lateral and posterior margins dark brown, with short stout setae (Fig. 10); pro- and mesonota with transverse mesal sclerotized ridge, less developed on metanotum; pronotum with middorsal ecdysial line, pair of anterolateral depressed areas (Fig. 10c); meso- and metanota slightly broader than long, without middorsal ecdysial lines (Fig. 10c); meso- and metathoracic pleural sclerite large, sclerotized; ventrally, prothorax with two pairs of thin, elongate sclerites, which converge medially; with a ventral thin intersegmental sclerite between meso- and metathorax; thoracic legs short, stout, similar in size, shape, and setation (Fig. 10b). Abdomen slightly compressed (Figs. 10b, 10c); all abdominal segments with sclerotized tergites: segments I and II with large tergite, covering most of dorsal area of the segment (Fig. 10c); segments III-VII with transverse tergite, lightly sclerotized, bearing many setae; segments VIII and IX with platelike tergite, heavily sclerotized, setose, forming a dorsal, almost circular operculum (Fig. 10d), which has a typical color pattern, with tergites dark brown with a pair of oval lighter areas (Fig. 10d); operculum closing posterior opening of the case. Pleurites of segments I and II small, with three and two setae respectively (Fig. 10b, in detail); those of segments III-VIII absent, but region with two small setae each one. Anal proleg short, setose with pair of long posterior setae; anal claw stout, curved to approximately $90^{\circ}$, with basal peglike setae. 
319 Laval case. Length 1.6-2.8 mm ( $\mathrm{n}=29)$. Made entirely of silk with bits of mineral material 320 incorporated, translucid; slightly compressed laterally; with poorly closed dorsal seam (Fig. 10a); 321 dorsal margin irregular; anterior and posterior openings circular.

322 Type material. Holotype male. PERU: Cusco, $20 \mathrm{rd} \mathrm{km} \mathrm{W} \mathrm{Quincemil,} \mathrm{Pte.} \mathrm{Saucipata,} \mathrm{Río}$ 323 Araza tributary, 13²0’13”'S 7051'15”'W 893 m. 22.viii.2012. APM Santos, DM Takiya leg., 324 pinned (MUSM). Paratypes. Same data as holotype, except 5 males, 7 females, pinned (DZRJ); 325 Same data as holotype, except 5 males, in alcohol (MUSM); PERU: Cusco, 19 rd km W 326 Quincemil, Rio Araza tributary, 13²0'10"' 7050'57’'W 874 m. 23-28.viii.2012. APM Santos, 327 DM Takiya leg., 16 males, 8 females, in alcohol (MUSM); same data, except 5 males, in alcohol 328 (DZRJ); same data, except malaise trap, 4 males, in alcohol (INPA); PERU: Cusco, 3 rd km E Quincemil, 13¹3'03'S 7043’40”'W 633 m. 20.viii.2012. APM Santos, DM Takiya leg., 1 female, pinned (DZRJ); PERU: Puno, 6 rd km W Mazuko, Pte. La Cigarra 130.'27'S 70²3'14'W 353 m. 01.ix.2012. APM Santos, DM Takiya leg., 5 females, pinned (DZRJ); same data, except 1 female, in alcohol (MUSM).

Additional material examined. Same data as holotype, 3 larvae, in alcohol (MUSM); PERU:

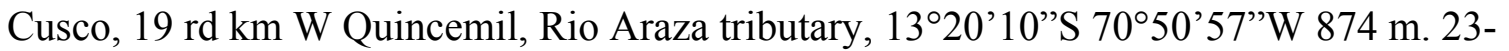
28.viii.2012. APM Santos, DM Takiya leg., 11 larvae, in alcohol (INPA); same data, except 18 337 (MUSM).

338 Etymology. The species name is an allusion to the Inca goddess Mama Ocllo (used as a noun in apposition), the "mother fertility". According to Inca mythology, Mama Ocllo was daughter of Apu Inti and Mama Quilla, and she married her brother Manco Capac. Together, Mama Ocllo and Manco Capac founded Cusco and guided the people, enabling the beginning of the Inca civilization.

343 Distribution. Peru (Cusco, Puno).

344 Remarks. In the field, B. mamaocllo sp. nov. can be recognized from other two Peruvian species of Byrsopteryx by the color pattern with a long longitudinal white band on each forewing (Fig. 6). Byrsopteryx species show no sexual dimorphism in color pattern (Harris \& Holzenthal, 1994), which have allowed male-female associations presented here. Byrsopteryx mamaocllo sp. nov. can be easily distinguished from other Byrsopteryx species also by its male genitalia; with segment VIII bearing a pair of short, posterior, spinelike processes on sternum, which are curved inwards and bordered by rounded, membranous structure (Figs. 8a, 8b); and a pair of short, heavily sclerotized, dorsolateral processes (Figs. 8a, 8d). See further comments on above Remarks of $B$. inti sp. nov. Females of $B$. mamaocllo sp. nov. also differ from those of other Byrsopteryx species by genitalia with the vaginal apparatus only slightly sclerotized, with anterior region rounded, and a posterior region mostly membranous (Fig. 9b).

Larvae of B. mamaocllo sp. nov. and of B. mancocapac sp. nov. are very similar to those previously described for other Byrsopteryx species, including general aspect of the case, the setation pattern of the head, and the sclerites. General aspects of Byrsopteryx larval morphology have been described in detail by Holzenthal \& Harris (1991) \& Santos \& Nessimian (2010). 
359 Considering the two Peruvian larvae described here, B. mamaocllo sp. nov. differ from $B$.

360

361

362

363

364

365

366

367

368

369

370

371

372

373

374

375

376

377

378

379

380

381

382

383

384

385

386

387

388

389

390

391

392

393

394

395

396

397

398

mancocapac sp. nov. by the: (1) almost circular operculum with two pairs of oval lighter areas, a pair on tergite VIII and another on IX (Fig. 10d), in B. mancocapac sp. nov. larvae the operculum is more rectangular; (2) case generally smaller than larva (Fig. 10a), in $B$. mancocapac sp. nov. its case is as long as larva; and (3) abdominal segment II with small pleurite bearing two setae (Fig. 10b), whereas in B. mancocapac sp. nov., it has three setae.

\section{Byrsopteryx mancocapac new species}

urn:lsid:zoobank.org:act:1D7BEBF4-38D5-4A54-8545-A48B7A066E4A

- Byrsopteryx sp. PE3 Santos, Nessimian \& Takiya, 2016:461. Phylogenetic placement. Figs. 11-14

Description. Adult male. Coloration. General color dark brown; head dorsum and mesoscutum densely covered with black setae, with no white setae; forewing with four distinct maculae of white setae: a longitudinal oval band at base of medial area, a trapezoidal macula near midcostal margin, a subapical spot near posterior margin of wing, and an apical spot, spreading towards costal margin (Fig. 11). Length. Total length 2.6-3.6 mm (n=23). Head. Unmodified. Antennae 18-articulated. Ocelli 3. Maxillary palpi 5-articulated; articles I and II very short and globular, article III very long, as long as articles IV and V combined; articles IV and V with similar lengths, each one about twice as long as wide. Thorax. Forewing venation strongly reduced; with distinct line of weakness; basal lobe apparently absent; semi-dome or other wing modification absent; retinaculum distinct (Fig. 12a). Hind wing venation strongly reduced; frenulum distinct, with two rows of three to five short, hooked setae (Fig. 12b). Tibial spur formula 0, 3, 4 . Abdomen. Segment VII without ventromesal process. Male genitalia. Segment VIII shorter dorsally than ventrally. Sternum with deep mesal incision posteriorly, forming pair of platelike lobes in ventral view, each one with rounded corners and bearing longer setae on the posterolateral quadrant and smaller setae surrounding the internal margin (Fig. 13a). Tergum with transverse row of long and stout setae near posterior margin (Fig. 13b). Segment IX recessed within segment VIII, projecting anteriorly through posterior portion of segment VII; with deep mesal incision anteriorly in dorsal and ventral views (Figs. 13a, 13b); narrowing anteriorly in lateral view (Fig. 13c); open dorsally; with pair of small, rounded posterior projections in ventral view, each one with acute beak on internal margin (Fig. 13a). Subgenital plate with lateral arms converging posteriorly to a single darkened apex, strongly downturned in lateral view (Fig. 13c); with strong horn-like process emerging from base of each arm (Fig. 13c). Inferior appendages positioned dorsolaterally; elongate, slender, almost parallel in ventral and dorsal views (Figs. 13a, 13b); in lateral view, each one with dorsal platelike projection at basal portion, narrowing to apex and downturned (Fig. 13c). Tergum $X$ with a basal trapezoid sclerite, with shallow incision in anterior margin in dorsal view (Fig. 13b); posterior portion conical and membranous. Phallus tubular, with slight constriction between basal and apical portions; basal portion short, less than half length of apical portion; with an acute sclerotized apical projection (Fig. 13c, 13d); membranous at apex (Fig. 13c).

Peer) reviewing PDF | (2021:09:66094:1:1:NEW 22 Nov 2021) 
399

400

401

402

403

404

405

406

407

408

409

410

411

412

413

414

415

416

417

418

419

420

421

422

423

424

425

426

427

428

429

430

431

432

433

434

435

436

437

438

Adult female. Unknown.

Larva (final instar). Length 2.0-3.8 mm ( $\mathrm{n}=28)$. Head brown to dark brown, unpigmented around eyes; quadrangular; frontoclypeal and coronal sutures indistinct; dorsum with reticulate pattern formed by microscopic setae; setae 9 very long; antennae 1-articulated, apical seta indistinct; mandibles without distinct teeth. Thoracic nota strongly sclerotized, brown, with lateral and posterior margins dark brown, with short stout setae; pro- and mesonota with transverse mesal sclerotized ridge, less developed on metanotum; pronotum with middorsal ecdysial line, pair of anterolateral depressed areas (Fig. 14c); meso- and metanota slightly broader than long, without middorsal ecdysial lines (Fig. 14c); meso- and metathoracic pleural sclerite large, sclerotized (Fig. 14b); ventrally, prothorax with two pairs of thin, elongate sclerites, which converge medially; with ventral thin intersegmental sclerite between meso- and metathorax; thoracic legs short, stout, similar in size, shape, and setation (Fig. 14b). Abdomen slightly compressed (Fig. 14c); all abdominal segments with sclerotized tergites: segments I and II with large tergite, covering most of dorsal area of the segment (Fig. 14c); segments III-VII with transverse tergite, lightly sclerotized, bearing many setae; segments VIII and IX with platelike tergite, heavily sclerotized, setose, forming a dorsal, subrectangular operculum (Fig. 14d), which has a typical color pattern, with tergites brown, with mesal, longitudinal darker area on tergite VIII and darker line near anterolateral margins, and darker border on anterior and lateral margins of tergite IX (Fig. 14d); operculum closing posterior opening of case. Pleurites of segments I and II small, each one with three setae (Fig. 14b, in detail); those of segments III-VIII absent, but region with two small setae each one. Anal proleg short, setose with pair of long posterior setae; anal claw stout, curved to approximately $90^{\circ}$, with basal peglike setae.

Laval case. Length $1.8-4.0 \mathrm{~mm}(\mathrm{n}=28)$. Made entirely of silk with bits of mineral material incorporated, slightly compressed laterally, with poorly closed dorsal seam (Fig. 14a); dorsal margin irregular; anterior and posterior openings circular.

Type material. Holotype male. PERU: Cusco, 20 rd km W Quincemil, Pte. Saucipata, Río Araza tributary, 1320'13"S 7051'15'W 893 m. 22.viii.2012. APM Santos, DM Takiya leg., pinned (MUSM). Paratypes. Same data as holotype, except 9 males, pinned (DZRJ); same data as holotype, except 7 males, in alcohol (MUSM); same data as holotype, except 1 male, in alcohol (DZRJ). PERU: Cusco, 3 rd km E Quincemil, 1313'03's 7043'40"W 633 m. 20.viii.2012. APM Santos, DM Takiya leg., 3 males, in alcohol (DZRJ). PERU: Puno, 6 rd km W Mazuko, Pte. La Cigarra, 1308'27’'S 70²3'14”'W 353 m. 01.ix.2012. APM Santos, DM Takiya leg., 4 males, pinned (DZRJ), 4 males, pinned (MUSM); same data, except, 3 males, in alcohol (INPA), 6 males, in alcohol (DZRJ).

Additional material examined. Same data as holotype, except 4 larvae, in alcohol (MUSM), 3 larvae, in alcohol (INPA). PERU: Cusco, 19 rd km W Quincemil, Rio Araza tributary, 13²0’10”S 7050'57’W 874 m. 26.viii.2012. APM Santos, DM Takiya leg., 8 larvae, in alcohol (DZRJ), 7 larvae, in alcohol (MUSM), 2 larvae, in alcohol (INPA). PERU: Puno, 6 rd km W Mazuko, Pte. La Cigarra, 1308'27’S 70²3'14”W 353 m. 01.ix.2012. APM Santos, DM Takiya 
439 leg., 4 larvae, in alcohol (DZRJ); same data, except 15 larvae, in alcohol (DZRJ); 15 larvae, in 440 alcohol (INPA); 18 larvae, in alcohol (MUSM)

441 Etymology. The species name is an allusion to Manco Capac (used as a noun in apposition), son 442 of Inti and Mama Quilla, according to some legends. Manco Capac and Mama Ocllo, his sister 443 and wife, were sent to Earth to find the best place to begin a civilization. They travelled to the 444 region which later became Cusco, where they established the center of the Inca Empire.

445 Remarks. Byrsopteryx mancocapac sp. nov. is very distinctive from the previous and other 446 species described in the genus. In the field, this new species can be easily recognized from others 447 occurring at same site by its coloration, whereas adults from both $B$. inti sp. nov. and $B$.

448 mamaocllo sp. nov. have head and mesoscutum densely covered by white setae (Figs. 3, 6), and 449 adults of $B$. mancocapac sp. nov. show only black setae on head and mesoscutum (Fig. 11). 450 Furthermore, males of $B$. mancocapac sp. nov. do not show the wing modification which is seen 451 in males of both $B$. inti sp. nov. and B. mamaocllo sp. nov. Male genitalia are also unique among 452 Byrsopteryx species, particularly due to the conspicuous spine-like, curved processes projecting 453 from dorsal region of subgenital plate (Figs. 13b, 13c). These processes superficially resemble

454

455

456

457

458

459

460

461

462

463

464

465

466

467

468

469

470

471

\section{Discussion}

473 Hydroptilids represent the most diverse caddisfly family (Morse et al., 2019), yet many

474 undescribed species remain unnamed in entomological collections. Here, we provided

475 descriptions for three new species of Byrsopteryx from Peru. Despite relevant works on Peruvian 476 caddisfly fauna, such as Flint $(1975,1980,1996)$, Flint \& Reyes (1991), Flint \& Bueno-Soria 477 (1998, 1999), and Harris \& Davenport (1992, 1999), no Byrsopteryx species had been described 478 or recorded from the country so far. As indicated by studies in other South American countries, 
479 we have a very limited knowledge on caddisfly diversity in the Neotropics (e.g., Ríos-Touma et

480

481

482

483

484

485

486

487

488

489

490

491

492

493

494

495

496

497

498

499

500

501

502

503

504

505

506

507

508

509

510

511

512

513

514

515

516

517

al., 2017 - Ecuador; Santos et al., 2020 - Brazil).

Byrsopteryx is a relatively small genus, now with 19 described species. The genus has been recorded from Mexico, Central America, north of South America, and south portion of Brazil (Holzenthal \& Calor, 2017; Vásquez-Ramos, Osorio-Ramírez \& Caro-Caro, 2020). Species usually show a limited geographic distribution, being associated to waterfalls and/or rocky streams. Adults are commonly seen active during daylight and usually they are not collected in high numbers using light (Harris \& Holzenthal, 1994) or Malaise traps. During collecting days, we saw many adults and larvae in the localities where we found Byrsopteryx, but very few specimens were collected by several days of Malaise trapping in the same site. Interestingly, the three species described here co-occur in these localities, but adults of $B$. mamaocllo sp. nov. were much more seen and collected than the other two species, and $B$. int $i$ sp. nov. being rarely represented among sampled specimens. In addition, despite the relatively high numbers of specimens of Byrsopteryx mancocapac sp. nov., we were not able to associate any female to this species.

Adult males of the species described here are very distinctive morphologically from other Byrsopteryx species, but they have typical features of this genus, such as the color pattern, the diurnal behavior, the reduced wing venation, and forewing with a distinct line of weakness, separating the posterobasal area (Flint, 1981). Larvae associated for two of the new species described here are also very similar to those previously described in the genus. The three new species, though unnamed, were previously included in the phylogenetic analyses presented by Santos, Nessimian \& Takiya (2016), which recovered the genus as monophyletic, as indicated earlier by Harris \& Holzenthal (1994).

In the present phylogenetic hypothesis $B$. mamaocllo sp. nov. grouped with $B$. inti sp. nov., although in the Bayesian analysis of Leucotrichiinae based on combined data (Santos, Nessimian \& Takiya, 2016), B. mamaocllo sp. nov. was recovered as sister to B. mirifica, the type species. However, the latter clade was not recovered by parsimony analysis of the same dataset nor it was statistically supported, possibly due to the lack of molecular data for $B$. mirifica. Furthermore, in Santos, Nessimian \& Takiya (2016), the clade B. mamaocllo sp. nov. + $B$. mirifica was found related to $B$. inti sp. nov. in both analyses and with moderate support. The sister group relationship of these two new species is also herein supported by strong morphological evidence (not shared by B. mirifica according to Harris \& Holzenthal, 1994): the presence of a semi-dome thickening on male forewings (Figs. 5a, 6a), a feature unique among Byrsopteryx species. Females of Byrsopteryx inti sp. nov. are unknown, but those of Byrsopteryx mamaocllo sp. nov. do not show this wing modification, and since this structure is associated with very long and specialized setae (Figs. 4a, 7a), it could be related to pheromone communication. Species of Leucotrichiinae can show different wing modifications, but they are commonly seen among species in the tribe Leucotrichiini. Among the Alisotrichiini, wing modifications are found in species of Cerasmatrichia Flint, Harris \& Botosaneanu, 1994 (Flint,

Peer) reviewing PDF | (2021:09:66094:1:1:NEW 22 Nov 2021) 
518 Harris \& Botosaneanu, 1994), with more sclerotized or inflated areas, but the feature described 519 here for these two new species is unique.

520 So far, only four Byrsopteryx species had their larvae described (Holzenthal \& Harris, 521 1992; Santos \& Nessimian, 2010) and here we describe larvae for two of the new species. These 522 larvae show typical features known for the genus, particularly the case poorly sealed dorsally; 523 prothorax with a pair of anterolateral depressed areas; and all abdominal segments with distinct 524 tergites, with tergites VIII and IX forming an operculum to close posterior opening of the case.

525 Both larvae herein described were associated to adult males based on comparison of COI 526 sequences, and additionally, pharate adults were assigned to B. mamaocllo sp. nov. due to the 527 general aspect of the case. Caddisfly larvae are conspicuous components of freshwater 528 ecosystems and are much more used in ecological or biomonitoring studies than adults.

529 However, Pes et al. (2018) pointed out that only $9.0 \%$ of Neotropical caddisfly species have their 530 immatures described, an indicative that more taxonomic studies should be developed in this 531 diverse and poorly known region, in particular, those including larva-adult associations.

532

\section{Conclusions}

534 The present paper is a contribution to the knowledge of Neotropical caddisflies, providing 535 descriptions of three new species of Byrsopteryx from Peru, the first formal descriptions of this 536 genus for the country. We were able to associate larvae and adults of two new species based on 537 comparison of a fragment of COI gene. Combining different sources of information, e.g., 538 morphological and molecular data, results in a better understanding of biodiversity, especially of 539 a megadiverse region. The present study highlights the demand for taxonomic work on 540 caddisflies from the Neotropics, a region increasingly threatened by deforestation due to 541 urbanization and uncontrolled exploration of natural resources.

542

\section{Acknowledgements}

544 We thank Dr. Isabela C. Rocha and two anonymous referees for comments that improved this 545 manuscript. Peruvian collecting permit was obtained with the help of G. Melo and A. Asenjo 546 (UFPR) and we are very grateful for field assistance provided by J. Rafael (INPA) and R.

547 Cavichioli (UFPR).

548

549

550

551

552

553

554

555

References

Akaike H. 1974. A new look at the statistical model identification. IEEE Transactions on Automatic Control 19(6):716-723.

Darriba D, Taboada GL, Doallo R, Posada D. 2012. jModelTest 2: more models, new heuristics and parallel computing. Nature methods 9(8): 772-772.

556 
557 Felsenstein J. 1985. Confidence limits on phylogenies: an approach using the bootstrap.

558

559

560

561

562

563

564

565

566

567

568

569

570

571

572

573

574

575

576

577

578

579

580

581

582

583

584

585

586

587

588

589

590

591

592

593

594

595

596

Evolution 39:783-791. https://doi.org/10.2307/2408678

Flint OS, Jr. 1975. Studies of Neotropical caddisflies, XX: Trichoptera collected by the Hamburg South-Peruvian Expedition. Entomologische Mitteilungen aus dem Zoologischen Museum Hamburg 4: 565-573.

Flint OS, Jr. 1980. VI. Trichoptera. In: Roback SW, ed. The Results of the Catherwood Foundation Bolivian-Peruvian Altiplano Expedition Part I Aquatic Insects except Diptera. Proceedings of the Academy of Natural Sciences of Philadelphia 132:213-217.

Flint OS, Jr. 1981. Studies of Neotropical caddisflies, XXVIII: The Trichoptera of the Río Limón Basin, Venezuela. Smithsonian Contributions to Zoology 330: 1-61. https://doi.org/10.5479/si.00810282.330

Flint OS, Jr. 1996. The Trichoptera collected on the expeditions to Parque Manu, Madre de Dios, Peru. In: Wilson DE, Sandoval A, eds. Manu, the biodiversity of southeastern Peru. Washington DC: Smithsonian Institution, 369-430.

Flint OS, Jr., Bueno-Soria J. 1998. Studies of Neotropical caddisflies LVI: descriptions of five new species of the genus Metrichia Ross (Trichoptera: Hydroptilidae) from Pakitza, Peru, with a checklist and bibliography of the described species of the genus. Proceedings of the Entomological Society of Washington 100: 489-496.

Flint OS, Jr., Bueno-Soria J. 1999 Studies of Neotropical caddisflies LVIII: new species of the genus Ochrotrichia Mosely (Trichoptera: Hydroptilidae) from Peru. Proceedings of the Entomological Society of Washington 101: 729-736.

Flint OS, Jr., Harris SC \& Botosaneanu L. 1994. Studies of neotropical caddisflies, L: the description of Cerasmatrichia, new genus, a relative of Alisotrichia, with the descriptions of new and old species and the larva (Trichoptera: Hydroptilidae). Proceedings of the Biological Society of Washington 107: 360-382.

Flint OS, Jr., Reyes L. 1991. Studies of Neotropical caddisflies, XLVI: the Trichoptera of the Río Moche Basin, Department of La Libertad, Peru. Proceedings of the Biological Society of Washington 104: 474-492.

Folmer O, Black M, Hoeh W, Lutz R, Vrijenhoek R. 1994. DNA primers for amplification of mitochondrial cytochrome $\mathrm{C}$ oxidase subunit I from diverse metazoan invertebrates. Molecular Marine Biology and Biotechnology 3:294-299.

Peer) reviewing PDF | (2021:09:66094:1:1:NEW 22 Nov 2021) 
597

598

599

600

601

602

603

604

605

606

607

608

609

610

611

612

613

614

615

616

617

618

619

620

621

622

623

624

625

626

627

628

629

630

631

632

633

634

635

636
Harris SC, Davenport LJ. 1992. New species of microcaddisflies from the Amazon region, with especial reference to northeastern Peru (Trichoptera: Hydroptilidae). Proceedings of the

Entomological Society of Washington 94: 454-470.

Harris SC, Davenport LJ. 1999. New species of Hydroptilidae (Trichoptera) from the Amazon region of northeastern Peru. Proceedings of the Entomological Society of Washington 101: 2638 .

Harris SC, Holzenthal RW. 1994. Hydroptilidae (Trichoptera) of Costa Rica and the Neotropics: Systematics of the genus Byrsopteryx Flint (Stactobiini). Journal of the New York Entomological Society 102: 154-192.

Holzenthal RW. 2008. Digital Illustration of Insects. American Entomologist 54: 218-221. https://doi.org/10.1093/ae/54.4.218

Holzenthal RW, Calor AR. 2017. Catalog of the Neotropical Trichoptera (Caddisflies). Zookeys, 654, 1-566. https://doi.org/10.3897/zookeys.654.9516

Holzenthal RW, Harris SC. 1991. The larva of Byrsopteryx mirifica Flint, with an assessment of the phylogenetic placement of the genus within the Leuchotrichiini (Trichoptera: Hydroptilidae). In: Tomaszewski C, ed. Proceedings of the 6th International Symposium on Trichoptera. Poznan: Adam Mickiewicz University Press, 403-407.

Kimura M. 1980. A simple method for estimating evolutionary rates of base substitutions through comparative studies nucleotides sequences. Journal of Molecular Evolution 16:111-120 https://doi.org/10.1007/BF01731581.

Kumar S, Stecher G, Li M, Knyaz C, Tamura K. 2018. MEGA X: Molecular Evolutionary Genetics Analysis across Computing Platforms. Molecular Biology and Evolution 35(6): 15471549. https://doi.org/10.1093/molbev/msy096

Marshall JE. 1979. A review of the genera of the Hydroptilidae (Trichoptera). Bulletin of the British Museum (Natural History) Entomology series 39:135-239.

Morse JC, Frandsen PB, Graf W, Thomas JA. 2019. Diversity and ecosystem services of Trichoptera. Insects 10, 125. https://doi.org/10.3390/insects10050125

Pes AMO, Holzenthal RW, Sganga JV, Santos APM, Barcelos-Silva P, Camargos LM. 2018. Order Trichoptera. In: Hamada N, Thorp JH, Rogers DC, eds. Keys to Neotropical Hexapoda,

Peer] reviewing PDF | (2021:09:66094:1:1:NEW 22 Nov 2021) 
637 Thorp and Covich's Freshwater Invertebrates. London: Academic Press, Elsevier, vol. 3, 237638324.

639

640 Ríos-Touma B, Holzenthal RW, Huisman J, Thomson R, Rázuri-Gonzales E. 2017. Diversity

641 and distribution of the Caddisflies (Insecta: Trichoptera) of Ecuador. PeerJ 5: e2851.

642 https://doi.org/10.7717/peerj.2851

643

644 Ross HH. 1944. The caddis flies, or Trichoptera, of Illinois. Bulletin of the Illinois Natural

645 History Survey 23: 1-326.

646

647 Santos APM, Dumas LL, Henriques-Oliveira AL, Souza WRM, Camargos LM, Calor AR, Pes

648 AM. 2020. Taxonomic Catalog of the Brazilian Fauna: order Trichoptera (Insecta), diversity and 649 distribution. Zoology 37: e46392. https://doi.org/10.3897/zoologia.37.e46392

650

651 Santos APM, Nessimian JL. 2010. Description of a new species of Byrsopteryx (Trichoptera:

652 Hydroptilidae) from Rio de Janeiro State, Brazil, including its immature stages. Zootaxa 2668:

$65344-54$.

654

655 Santos APM, Nessimian JL, Takiya DM. 2016. Revised classification and evolution of 656 leucotrichiine microcaddisflies (Trichoptera: Hydroptilidae) based on morphological and

657 molecular data. Systematic Entomology 41: 458-480. https://doi.org/10.1111/syen.12168

658

659 Simon C, Frati F, Beckenbach A, Crespi B, Liu H, Flook P. 1994. Evolution, weighting and 660 phylogenetic utility of mitochondrial gene sequences and a compilation of conserved polymerase 661 chain reaction primers. Annals of the Entomological Society of America 87:651-701.

662 https://doi.org/10.1093/aesa/87.6.651.

663

664 Vásquez-Ramos JM, Osorio-Ramírez DP, Caro-Caro CI. 2020. First record of the larvae

665 Byrsopteryx Flint, 1981 (Trichoptera: Hydroptilidae) in Colombia. Revista de la Academia

666 Colombiana de Ciencias Exactas, Físicas y Naturales 44(171): 482-492.

667 https://doi.org/10.18257/raccefyn.1025

668

669 


\section{Figure captions}

671

672 Figure 1. Collecting localities of specimens of new Byrsopteryx species described here. (A)

673 Tributary of Río Araza, Cusco, Peru. (B) Pennsylvania trap being set up by APMS near Puente

674 Saucipata, close to a tributary of Río Araza, Cusco, Peru. (C) Tributary of Río Araza, near

675 Puente La Cigarra, Cusco, Peru. (D) Stream near Quincemil, Cusco, Peru.

676

677 Figure 2. Maximum likelihood $(-\ln \mathrm{L}=3322.784548)$ tree of COI sequences of Byrsopteryx

678 analyzed under GTR $+\mathrm{G}+\mathrm{I}$. Numbers above branches are bootstrap percentages. Details of

679 specimen vouchers are in Table 1.

680

681

Figure 3. Byrsopteryx inti sp. nov., adult. (A) Holotype male (pinned), lateral habitus. (B) Live

682 adult on a rocky surface.

683

684

Figure 4. Byrsopteryx inti sp. nov., male wings (paratype). (A) Forewing, showing semi-dome

685 process. (B) Forewing. (C) Hind wing.

686

687

Figure 5. Byrsopteryx inti sp. nov., male genitalia (holotype). (A) Ventral view. (B) Sternum

688 VIII, subgenital plate, and inferior appendages, caudal view. (C) Dorsal view. (D) Lateral view.

689 (E) Phallus, dorsal view. (F) Phallus, lateral view. Abbreviations: seg. - segment, m. pr. -

690 median process (segment VIII), pv. pr. - posteroventral process (segment VIII), dl. pr. -

691 dorsolateral process (segment VIII), ter. X - tergum X, sub. pl. - subgenital plate, inf. app. -

692 inferior appendage.

693

694 Figure 6. Byrsopteryx mamaocllo sp. nov., adult. (A) Holotype male (pinned), dorsal habitus. (B) 695 Live adult in a small pit over rocky surface.

696

697

Figure 7. Byrsopteryx mamaocllo sp. nov., male wings (paratype). (A) Forewing, showing semi-

698 dome process. (B) Forewing. (C) Hind wing.

699

700 Figure 8. Byrsopteryx mamaocllo sp. nov., male genitalia (holotype). (A) Ventral view. (B)

701 Posteroventral processes of segment VIII, caudal view. (C) Dorsal view. (D) lateral view. (E)

702 Phallus, dorsal view. (F) Phallus, lateral view. Abbreviations: seg. - segment, pv. pr. -

703 posteroventral process (segment VIII), dl. pr. - dorsolateral process (segment VIII), ter. X -

704 tergum X, sub. pl. - subgenital plate, inf. app. - inferior appendage.

705

706

Figure 9. Byrsopteryx mamaocllo sp. nov., female genitalia. (A) Segments VIII, IX, and X,

707 ventral view. (B) Vaginal apparatus, ventral view. Abbreviation: seg. - segment.

708 
709 Figure 10. Byrsopteryx mamaocllo sp. nov., larva. (A) Lateral habitus with case. (B) Lateral

710 habitus without case. (C) Dorsal habitus. (D) Operculum, dorsocaudal view.

711

712 Figure 11. Byrsopteryx mancocapac sp. nov., adult. (A) Paratype male (pinned), dorsal habitus.

713 (B) Live adult on a rocky surface.

714

715 Figure 12. Byrsopteryx mancocapac sp. nov., male wings. (A) Forewing. (B) Hind wing.

716

717 Figure 13. Byrsopteryx mancocapac sp. nov., male genitalia (holotype). (A) Ventral view. (B)

718 Dorsal view. (C) Lateral view. (D) Phallus, dorsal view. (E) Phallus, lateral view. Abbreviations:

719 seg. - segment, pos. pj. - posterior projection (segment IX), ter. X - tergum X, bas. scl. - basal

720 sclerite (tergum X), sub. pl. - subgenital plate, hor. pr. - horn-like process (subgenital plate), inf.

721 app. - inferior appendage.

722

723 Figure 14. Byrsopteryx mancocapac sp. nov., larva. (A) Lateral habitus with case. (B) Lateral

724 habitus without case. (C) Dorsal habitus. (D) Operculum, dorsocaudal view.

725

726 Table 1. Species of Byrsopteryx and other Leucotrichiinae with COI sequences used in this

727 study, with respective information of voucher specimen and GenBank accession numbers.

728

729 Supplementary File 1. NEXUS matrix of COI sequences of Byrsopteryx and Celaenotrichia. 730

731 Supplementary Table 1. K2P distances among 20 COI sequences of nine Byrsopteryx species 732 sampled. 


\section{Table 1 (on next page)}

Voucher specimen and GenBank accession numbers.

Species of Byrsopteryx and other Leucotrichiinae with COI sequences used in this study, with respective information of voucher specimen and GenBank accession numbers. 
1 Table 1. Species of Byrsopteryx and other Leucotrichiinae with COI sequences used in this study, with 2 respective information of voucher specimen and GenBank accession numbers.

\begin{tabular}{|c|c|c|c|c|}
\hline Species & Voucher code & $\begin{array}{l}\text { Life stage/ } \\
\text { adult } \\
\text { gender }\end{array}$ & $\begin{array}{l}\text { Country and } \\
\text { state/province }\end{array}$ & $\begin{array}{c}\text { GenBank } \\
\text { accession number }\end{array}$ \\
\hline $\begin{array}{l}\text { B. espinhosa Harris \& } \\
\text { Holzenthal, } 1994\end{array}$ & ENT0005 & & $\begin{array}{l}\text { Brazil, Rio de } \\
\text { Janeiro }\end{array}$ & KU094932 \\
\hline $\begin{array}{l}\text { B. carioca Santos \& } \\
\text { Nessimian, } 2010\end{array}$ & ENT0056 & & $\begin{array}{l}\text { Brazil, Rio de } \\
\text { Janeiro }\end{array}$ & KU094939 \\
\hline $\begin{array}{l}\text { B. abrelata Harris \& } \\
\text { Holzenthal,1994 }\end{array}$ & ENT0068 & & $\begin{array}{l}\text { Brazil, Rio de } \\
\text { Janeiro }\end{array}$ & KU094942 \\
\hline $\begin{array}{l}\text { B. esparta Harris \& } \\
\text { Holzenthal, } 1994\end{array}$ & ENT0123 & & $\begin{array}{l}\text { Costa Rica, } \\
\text { Puntarenas }\end{array}$ & KU094953 \\
\hline B. inti sp.nov. & ENT0702 & male & Peru, Cusco & KU094974 \\
\hline B. mamaocllo sp. nov. & ENT0703 & male & Peru, Cusco & KU094975 \\
\hline B. mamaocllo sp. nov. & ENT5516 & male & Peru, Cusco & OK340604 \\
\hline B. mamaocllo sp. nov. & ENT5519 & larva & Peru, Cusco & OK340605 \\
\hline B. mancocapac sp. nov. & ENT0704 & male & Peru, Cusco & KU094976 \\
\hline B. mancocapac sp. nov. & ENT5408 & larva & Peru, Cusco & OK340606 \\
\hline B. mancocapac sp. nov. & ENT5409 & larva & Peru, Cusco & OK340607 \\
\hline B. mancocapac sp. nov. & ENT5410 & larva & Peru, Cusco & OK340608 \\
\hline B. mancocapac sp. nov. & ENT5411 & larva & Peru, Cusco & OK340609 \\
\hline B. mancocapac sp. nov. & ENT5413 & larva & Peru, Cusco & OK340610 \\
\hline B. mancocapac sp. nov. & ENT5414 & larva & Peru, Cusco & OK340611 \\
\hline B. mancocapac sp. nov. & ENT5494 & male & Peru, Cusco & OK340612 \\
\hline $\begin{array}{l}\text { B. gomezi Harris \& } \\
\text { Holzenthal, } 1994\end{array}$ & UMSP000035603 & & $\begin{array}{l}\text { Costa Rica, } \\
\text { Puntarenas }\end{array}$ & KX107513 \\
\hline $\begin{array}{l}\text { B. gomezi Harris \& } \\
\text { Holzenthal, } 1994\end{array}$ & - & & - & AF436490 \\
\hline $\begin{array}{l}\text { B. tapanti Harris \& } \\
\text { Holzenthal, } 1994\end{array}$ & UMSP000075777 & & $\begin{array}{l}\text { Costa Rica, } \\
\text { Cartago }\end{array}$ & HQ971757 \\
\hline $\begin{array}{l}\text { Celaenotrichia edwardsi } \\
\text { Mosely, } 1934\end{array}$ & UMSP000038367 & & $\begin{array}{c}\text { Chile, } \\
\text { Araucania }\end{array}$ & HQ971758 \\
\hline
\end{tabular}

3 


\section{Figure 1}

Collecting localities of specimens of new Byrsopteryx species described here.

Collecting localities of specimens of new Byrsopteryx species described here. (A) Tributary of Río Araza, Cusco, Peru. (B) Pennsylvania trap being set up by APMS near Puente Saucipata, close to a tributary of Río Araza, Cusco, Peru. (C) Tributary of Río Araza, near Puente La Cigarra, Cusco, Peru. (D) Stream near Quincemil, Cusco, Peru. 


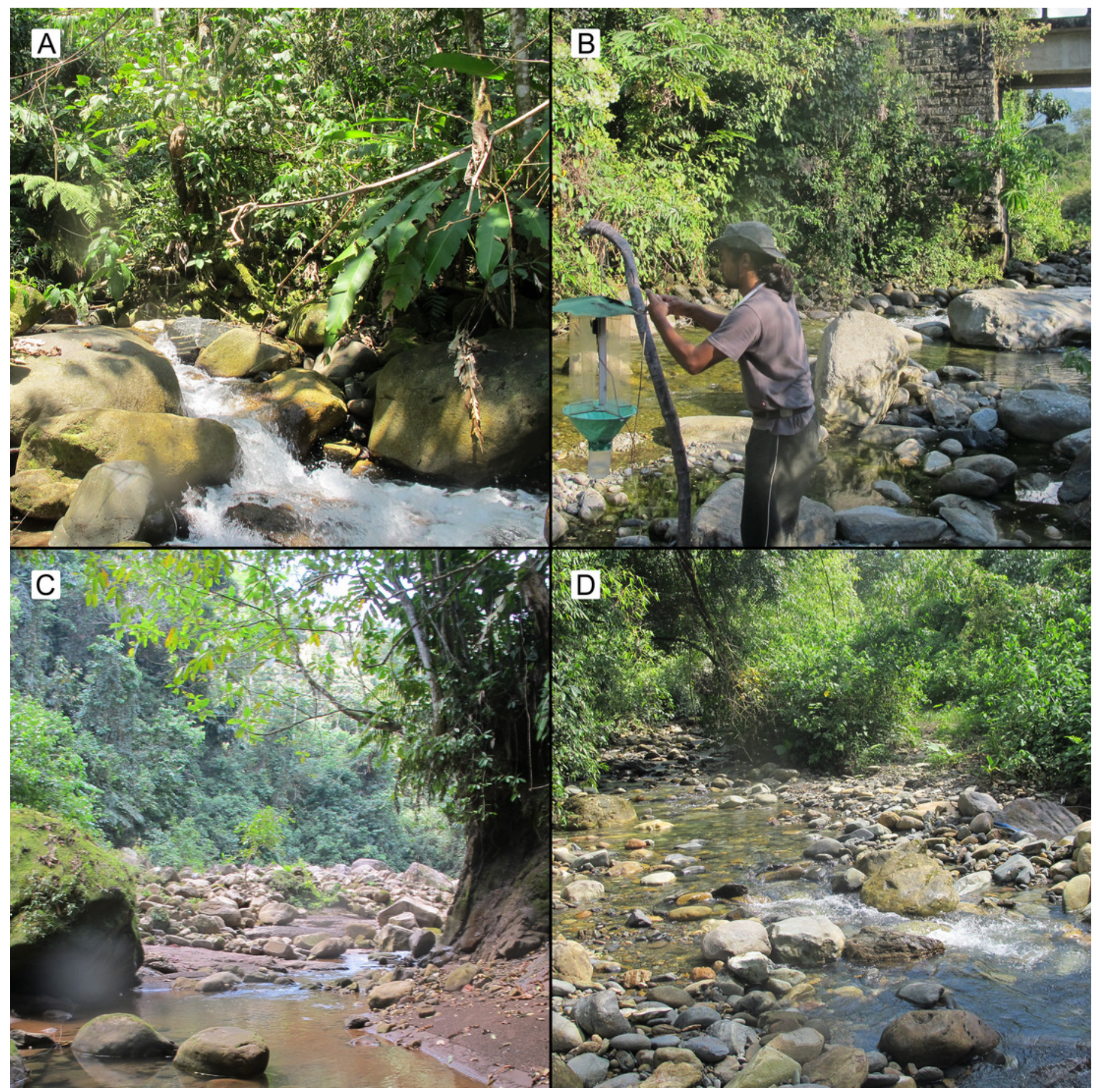




\section{Figure 2}

Maximum likelihood tree of COI sequences of Byrsopteryx.

Maximum likelihood (-InL $=3322.784548$ ) tree of COI sequences of Byrsopteryx analyzed under $\mathrm{GTR}+\mathrm{G}+\mathrm{I}$. Numbers above branches are bootstrap percentages. Details of specimen vouchers are in Table 1.

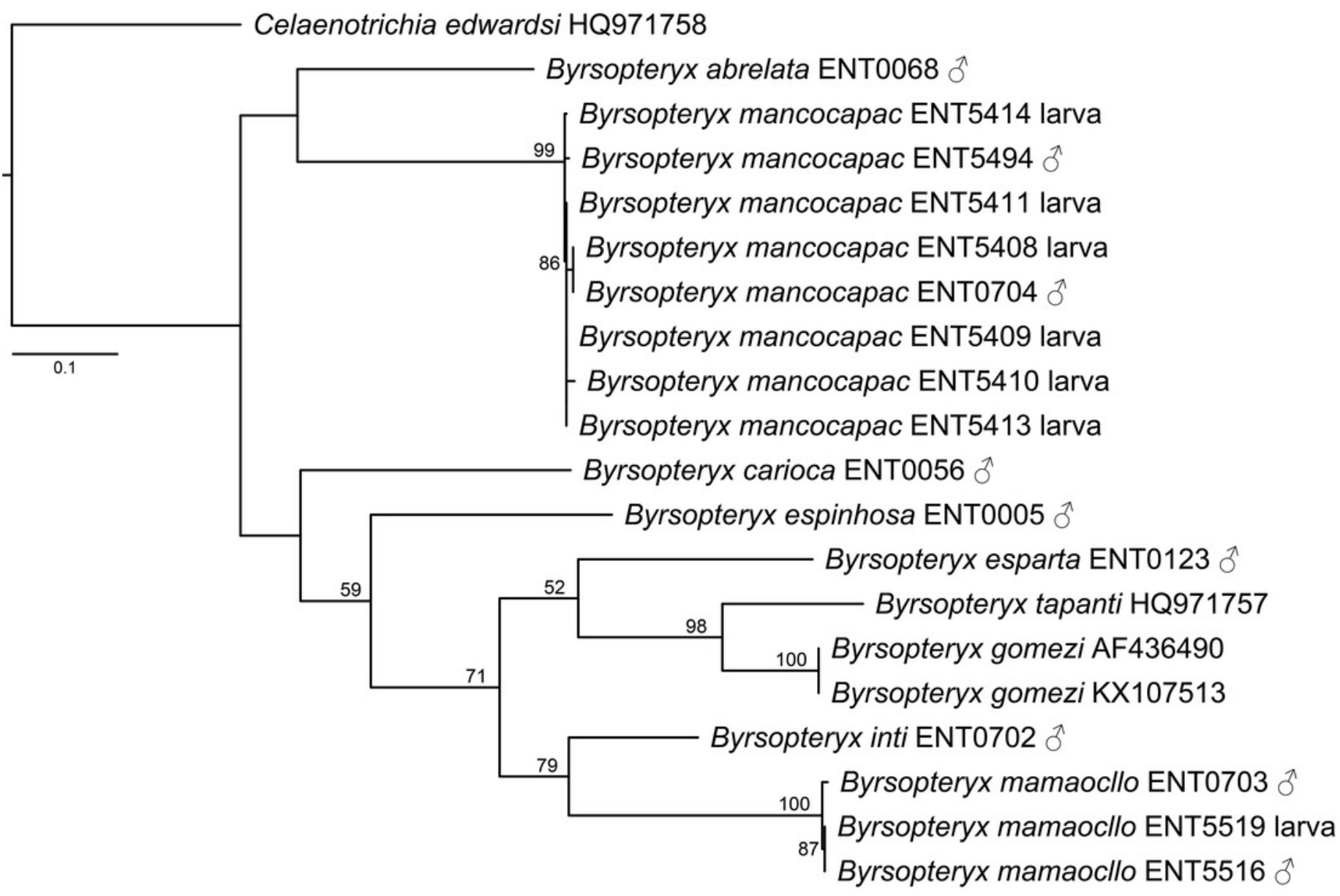




\section{Figure 3}

Byrsopteryx inti sp. nov., adult.

Byrsopteryx inti sp. nov., adult. (A) Holotype male (pinned), lateral habitus. (B) Live adult on a rocky surface.

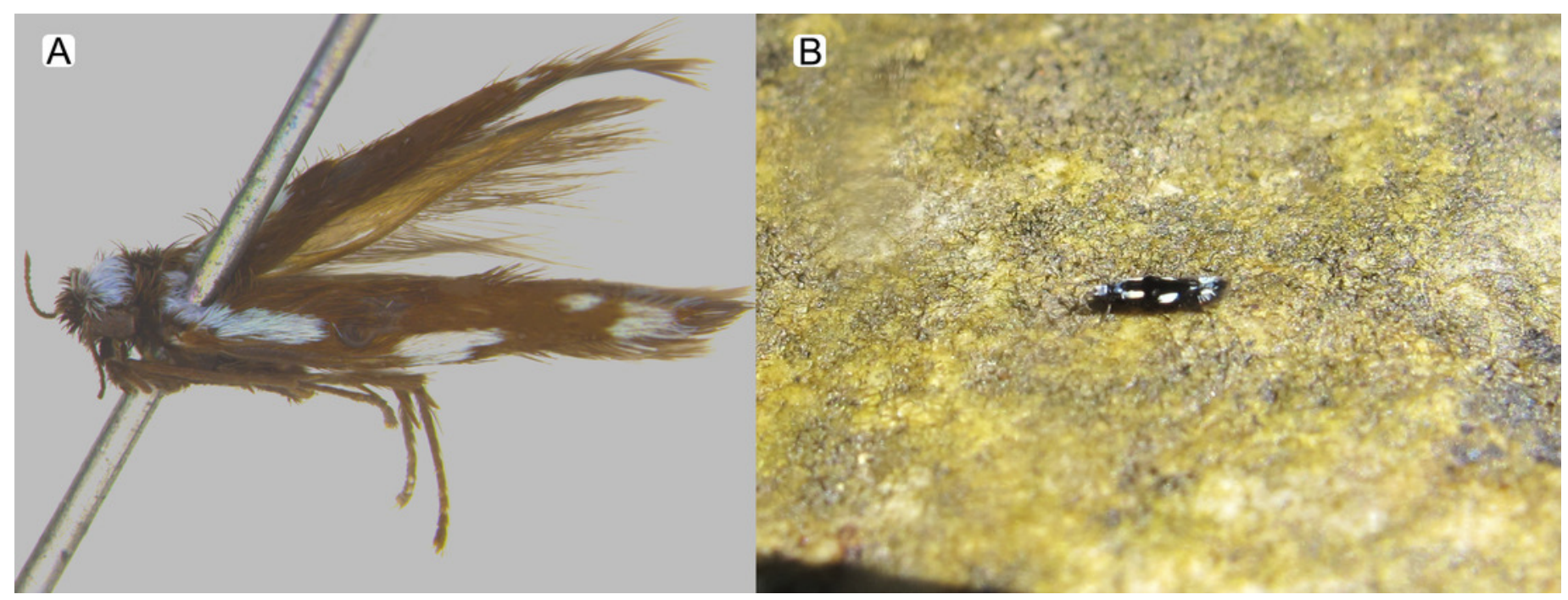


Figure 4

Byrsopteryx inti sp. nov., male wings (paratype).

Byrsopteryx inti sp. nov., male wings (paratype). (A) Forewing, showing semi-dome process.

(B) Forewing. (C) Hind wing.
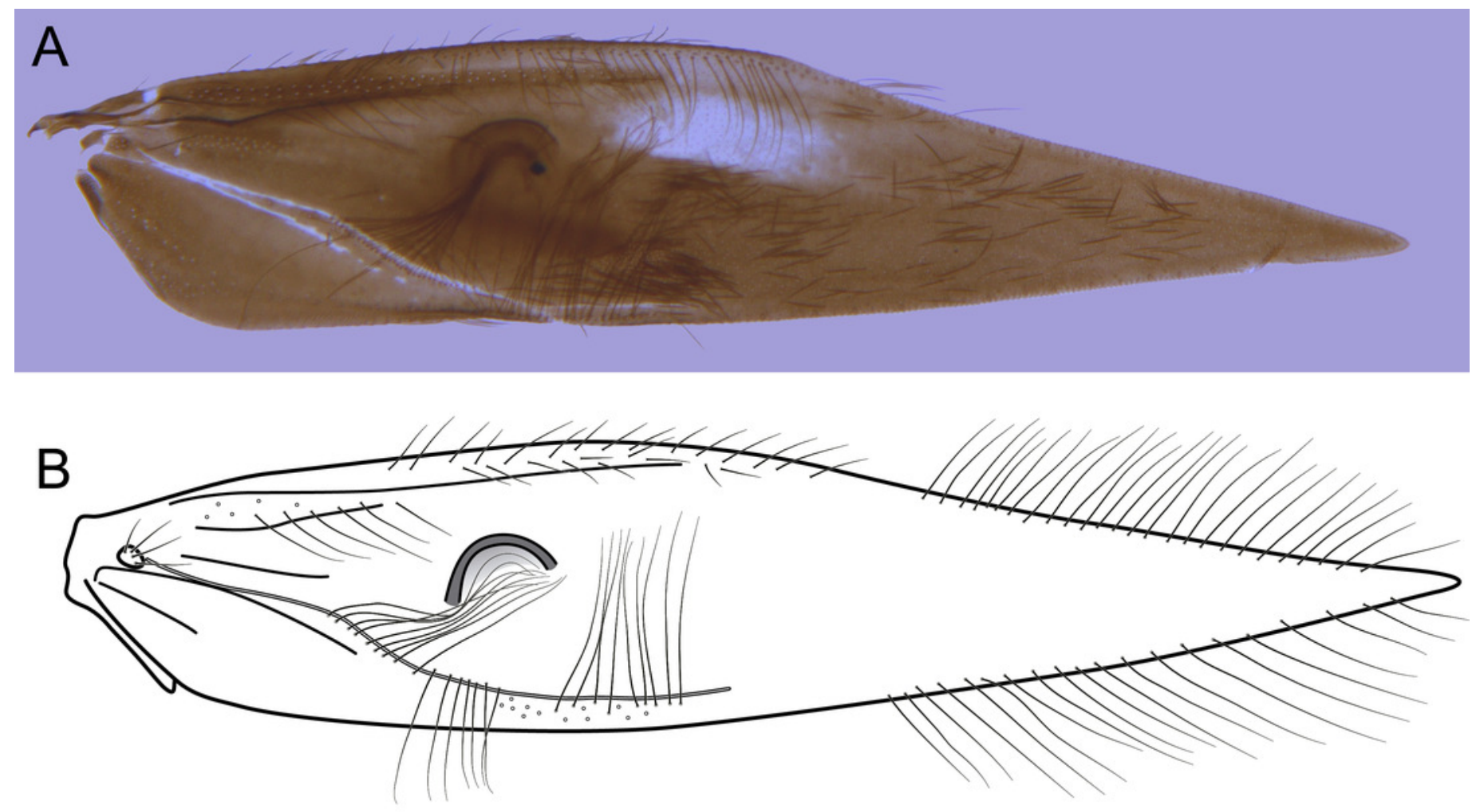

C

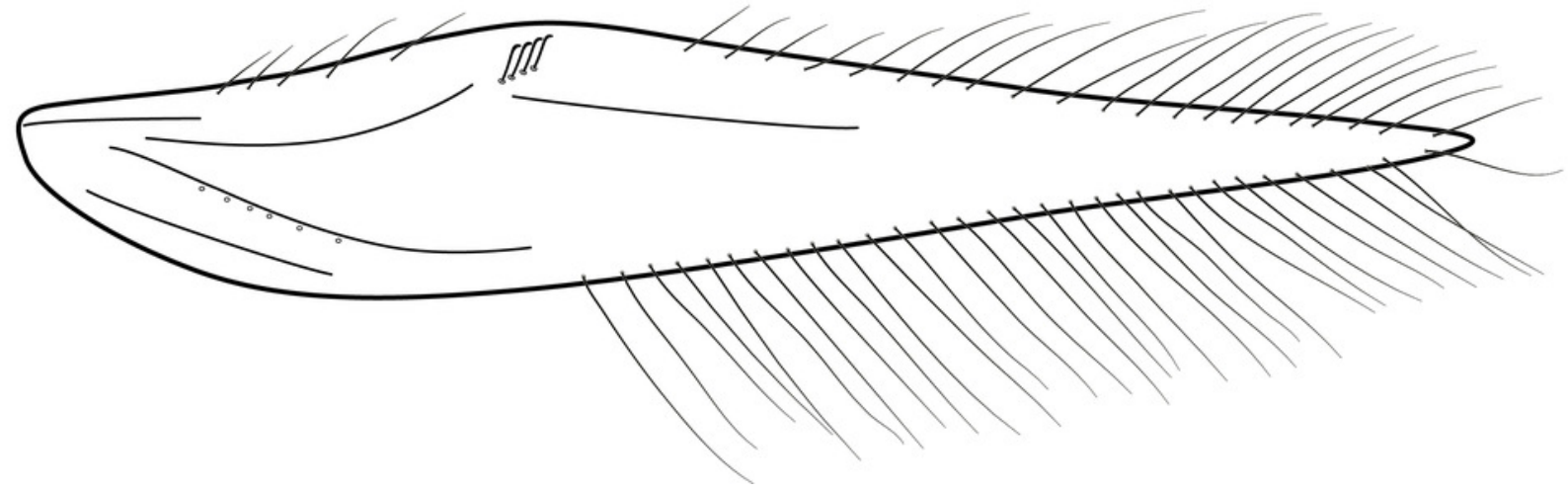




\section{Figure 5}

Byrsopteryx inti sp. nov., male genitalia (holotype).

Byrsopteryx inti sp. nov., male genitalia (holotype). (A) Ventral view. (B) Sternum VIII, subgenital plate, and inferior appendages, caudal view. (C) Dorsal view. (D) Lateral view. (E) Phallus, dorsal view. (F) Phallus, lateral view. Abbreviations: seg. - segment, m. pr. - median process (segment VIII), pv. pr. - posteroventral process (segment VIII), dl. pr. - dorsolateral process (segment VIII), ter. $X$ - tergum $X$, sub. pl. - subgenital plate, inf. app. - inferior appendage. 


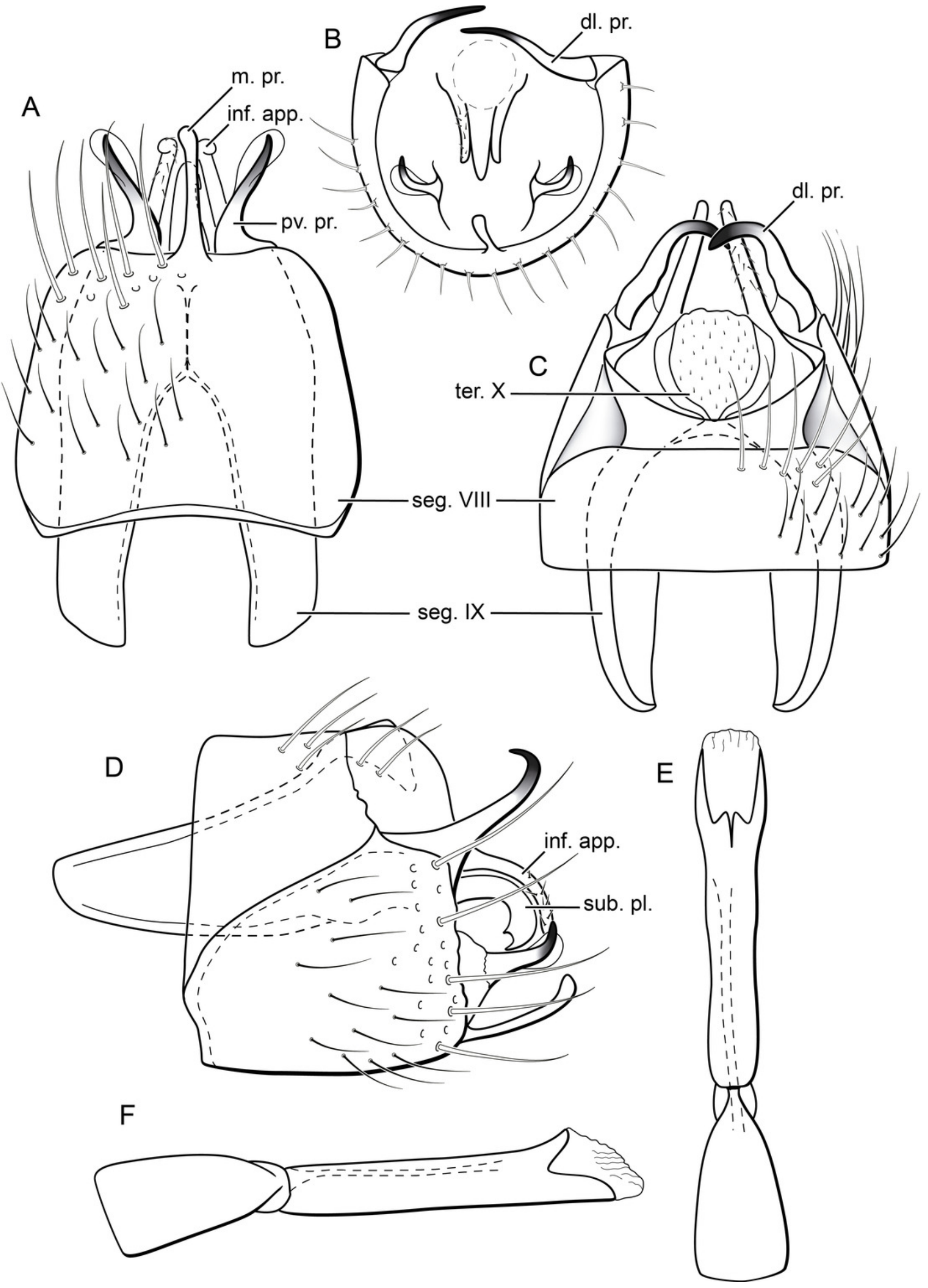




\section{Figure 6}

Byrsopteryx mamaocllo sp. nov., adult.

Byrsopteryx mamaocllo sp. nov., adult. (A) Holotype male (pinned), dorsal habitus. (B) Live adult in a small pit over rocky surface.

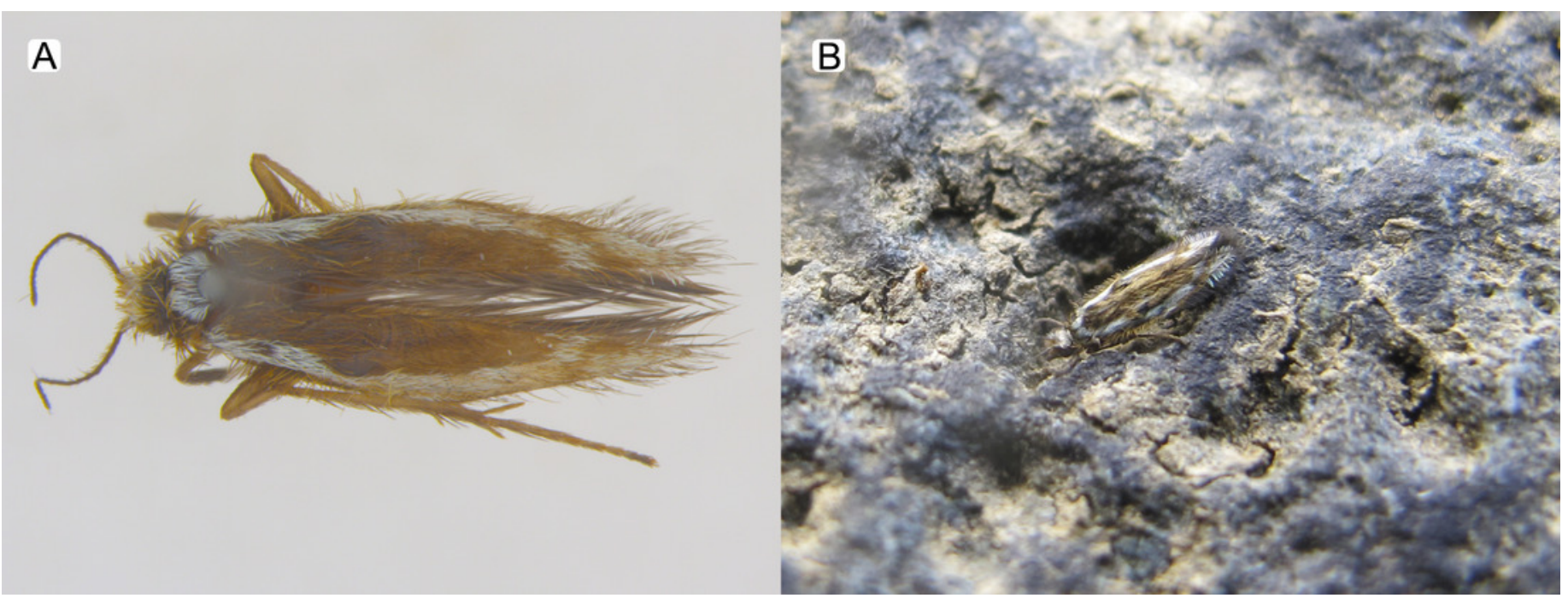


Figure 7

Byrsopteryx mamaocllo sp. nov., male wings (paratype).

Byrsopteryx mamaocllo sp. nov., male wings (paratype). (A) Forewing, showing semi-dome process. (B) Forewing. (C) Hind wing.
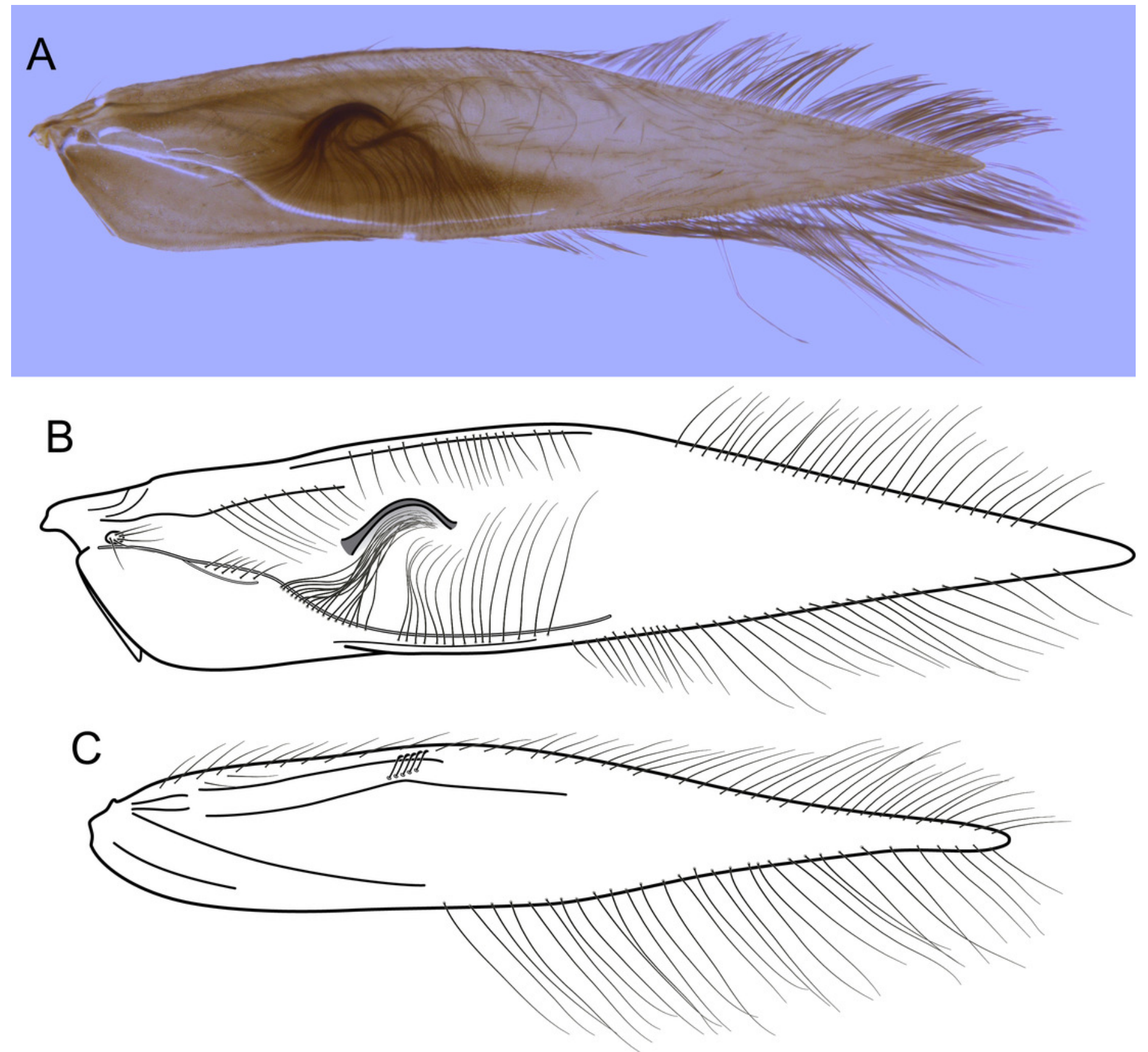


\section{Figure 8}

Byrsopteryx mamaocllo sp. nov., male genitalia (holotype).

Byrsopteryx mamaocllo sp. nov., male genitalia (holotype). (A) Ventral view. (B)

Posteroventral processes of segment VIII, caudal view. (C) Dorsal view. (D) lateral view. (E) Phallus, dorsal view. (F) Phallus, lateral view. Abbreviations: seg. - segment, pv. pr. posteroventral process (segment VIII), dl. pr. - dorsolateral process (segment VIII), ter. X tergum X, sub. pl. - subgenital plate, inf. app. - inferior appendage. 


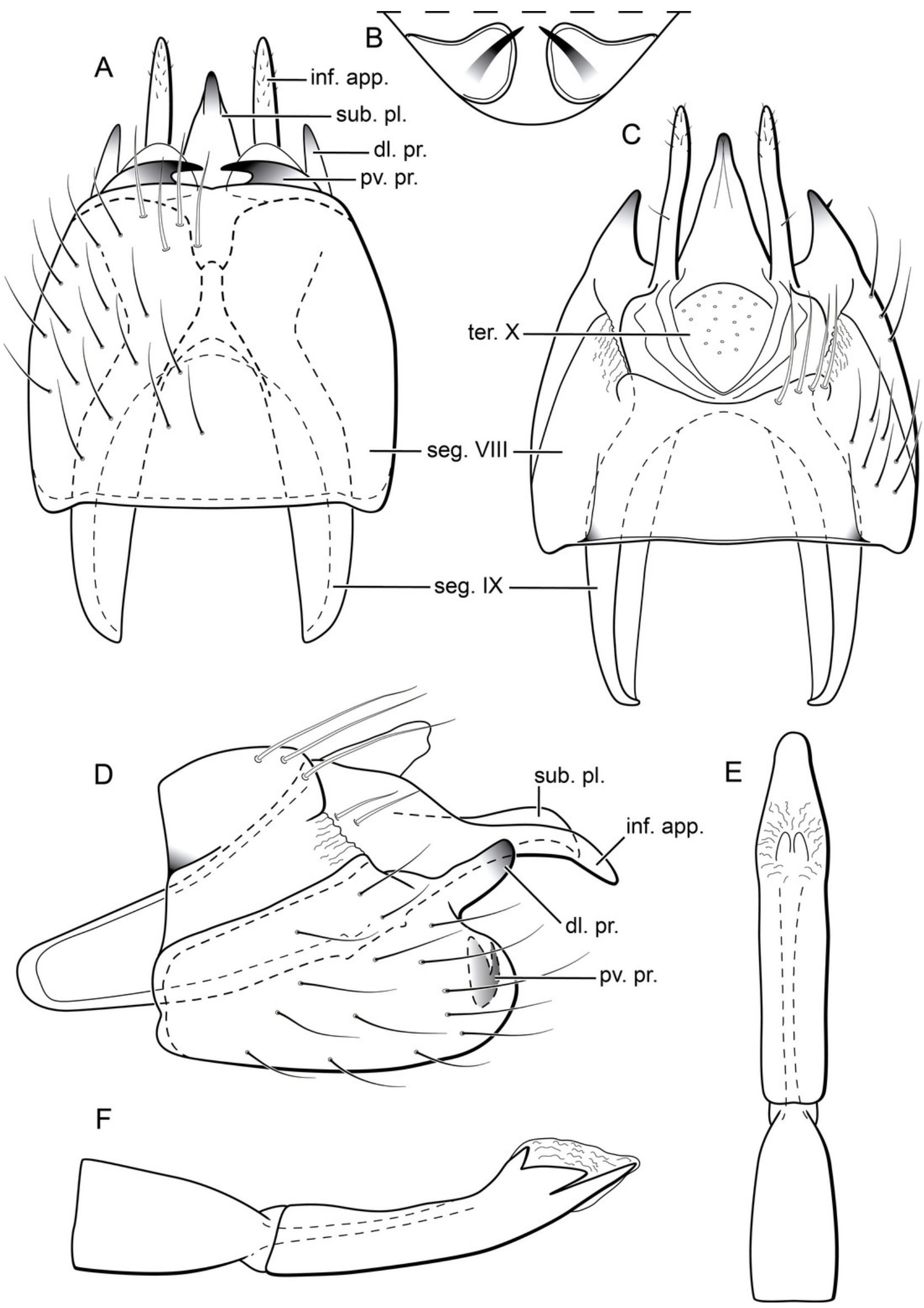

Peer] reviewing PDF | (2021:09:66094:1:1:NEW 22 Nov 2021) 
Figure 9

Byrsopteryx mamaocllo sp. nov., female genitalia.

Byrsopteryx mamaocllo sp. nov., female genitalia. (A) Segments VIII, IX, and X, ventral view.

(B) Vaginal apparatus, ventral view. Abbreviation: seg. - segment. 


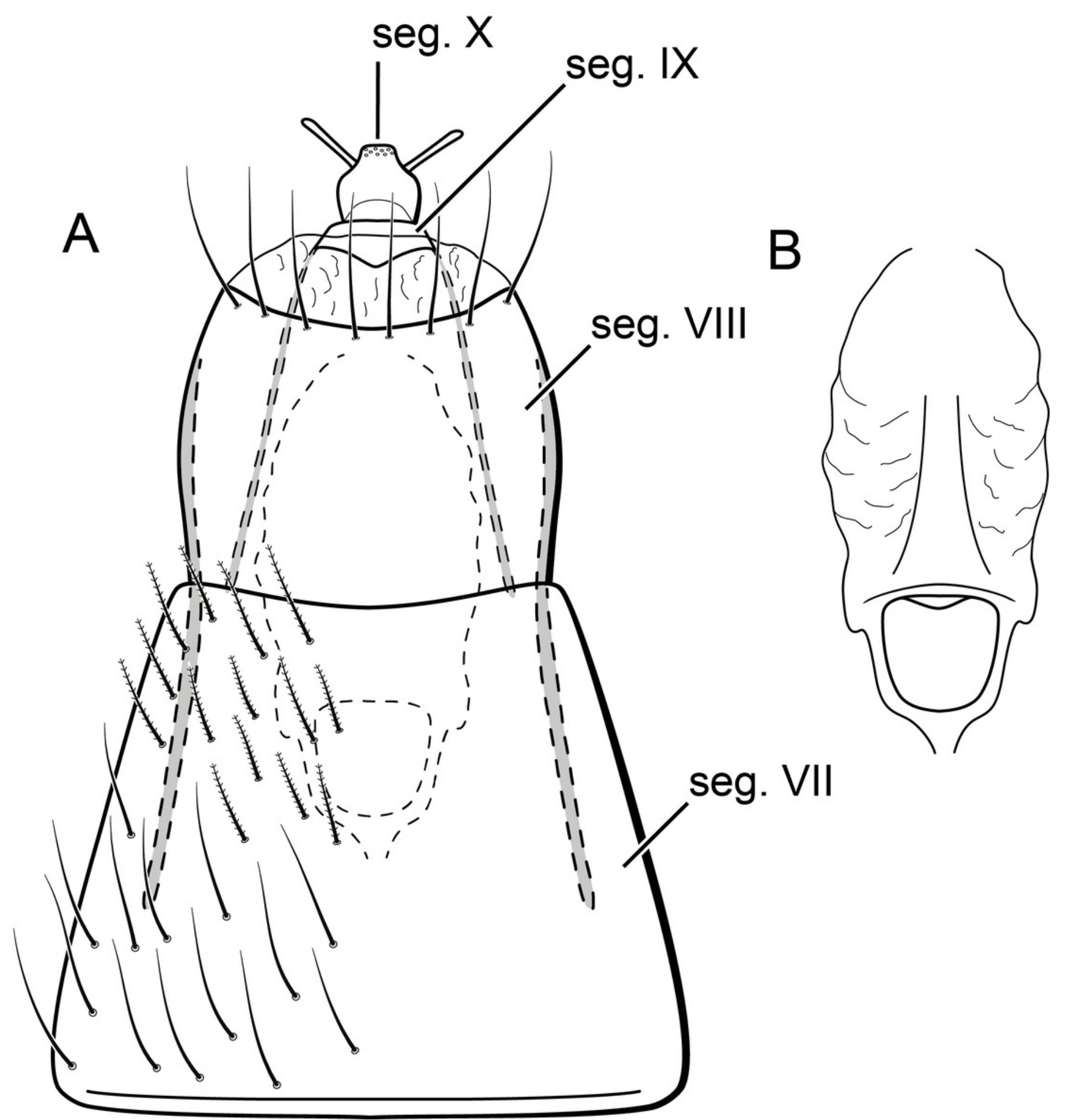




\section{Figure 10}

Byrsopteryx mamaocllo sp. nov., larva.

Byrsopteryx mamaocllo sp. nov., larva. (A) Lateral habitus with case. (B) Lateral habitus without case. (C) Dorsal habitus. (D) Operculum, dorsocaudal view.

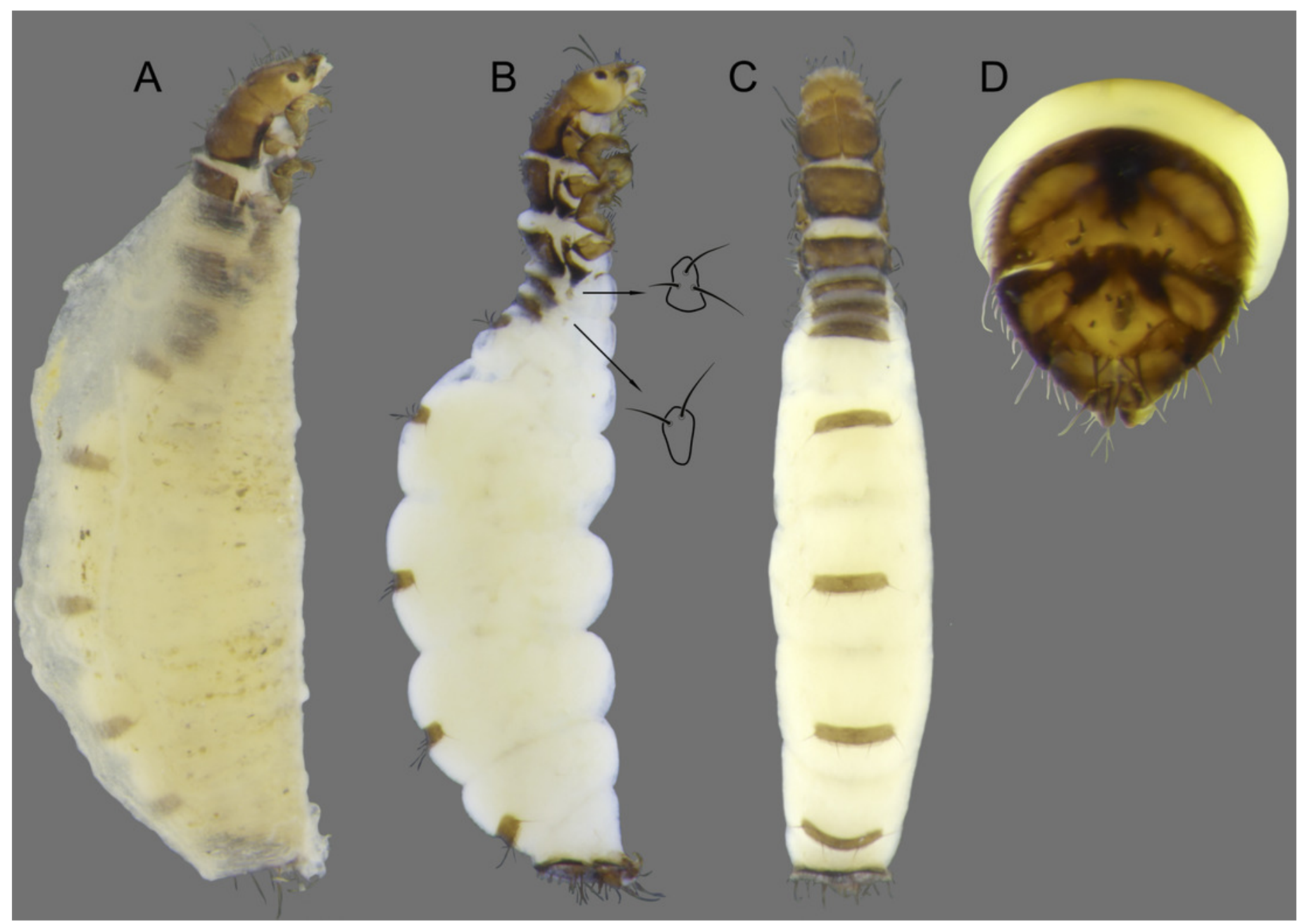




\section{Figure 11}

Byrsopteryx mancocapac sp. nov., adult.

Byrsopteryx mancocapac sp. nov., adult. (A) Paratype male (pinned), dorsal habitus. (B) Live adult on a rocky surface.

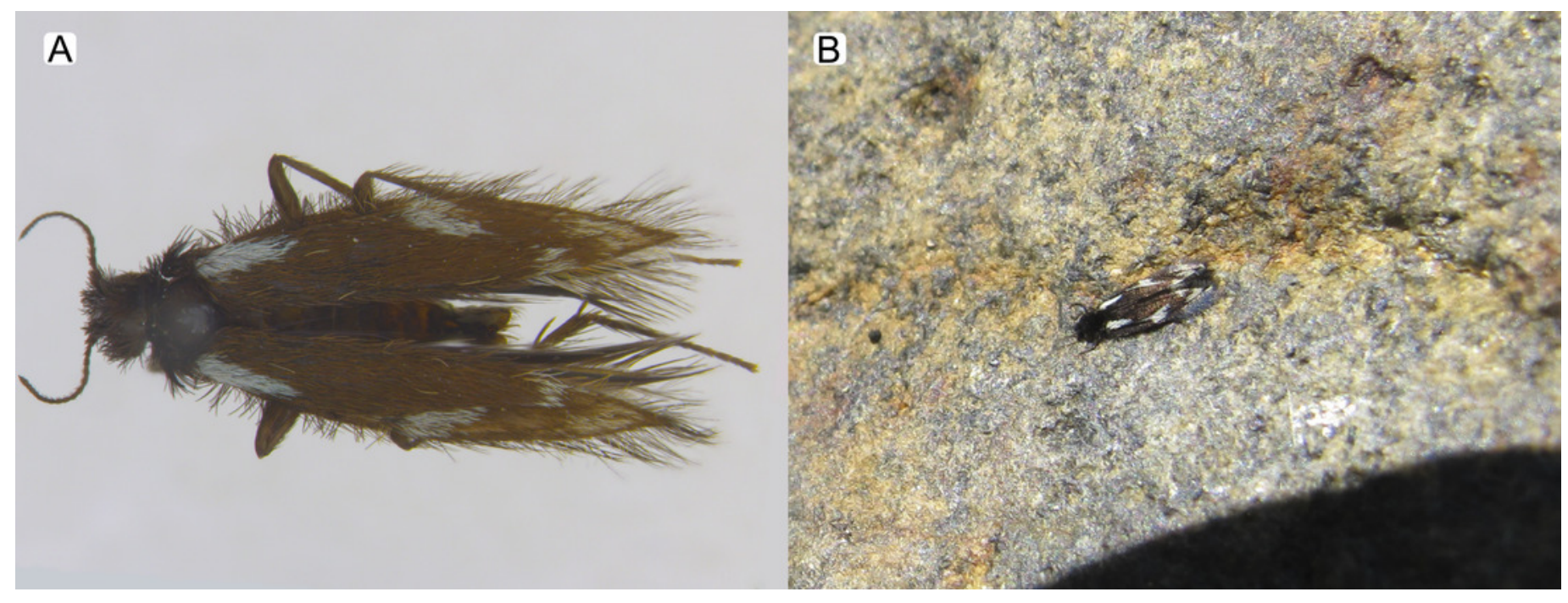


Figure 12

Byrsopteryx mancocapac sp. nov., male wings.

Byrsopteryx mancocapac sp. nov., male wings. (A) Forewing. (B) Hind wing.

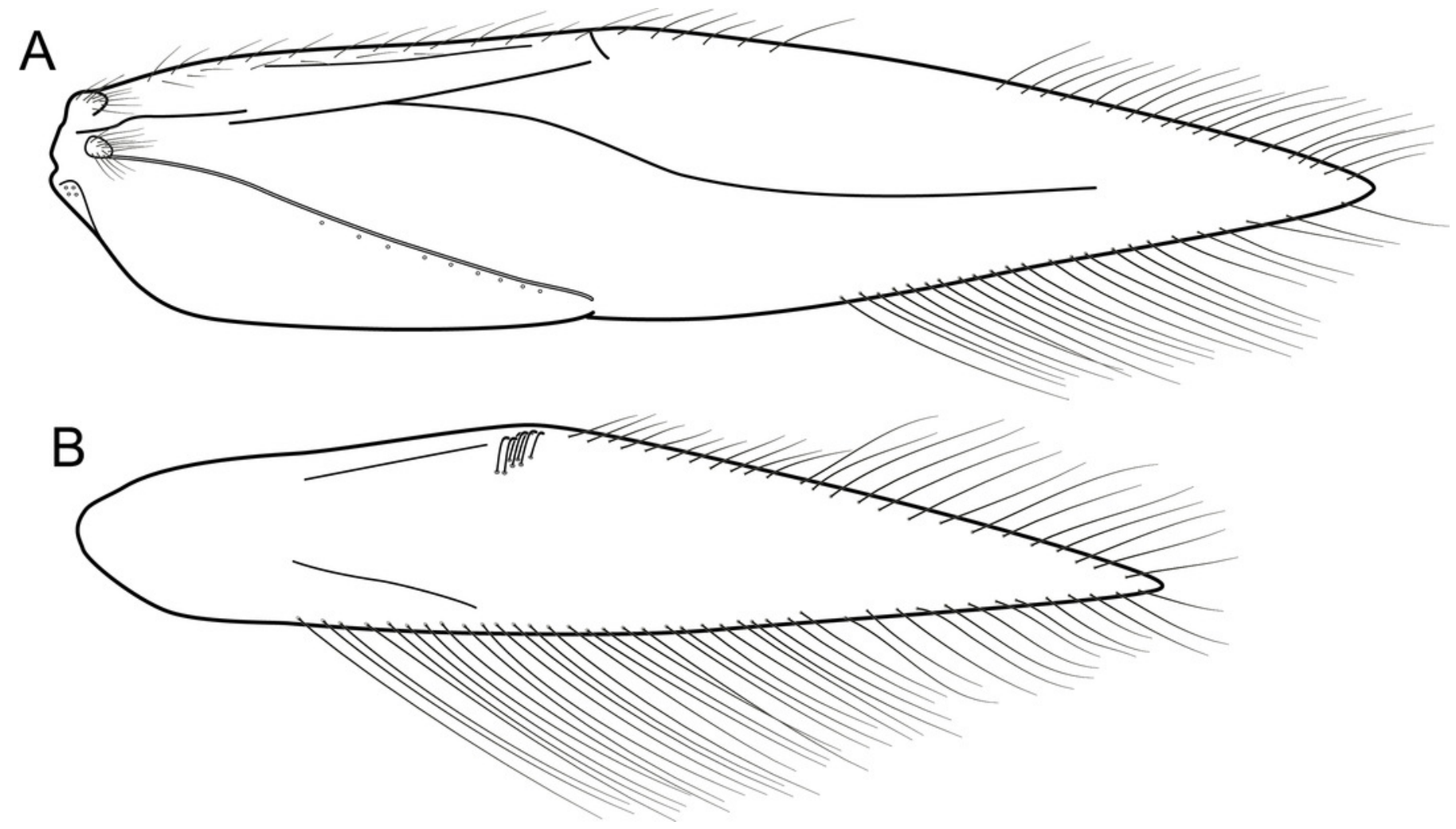




\section{Figure 13}

Byrsopteryx mancocapac sp. nov., male genitalia (holotype).

Byrsopteryx mancocapac sp. nov., male genitalia (holotype). (A) Ventral view. (B) Dorsal view. (C) Lateral view. (D) Phallus, dorsal view. (E) Phallus, lateral view. Abbreviations: seg. segment, pos. pj. - posterior projection (segment IX), ter. X - tergum X, bas. scl. - basal sclerite (tergum X), sub. pl. - subgenital plate, hor. pr. - horn-like process (subgenital plate), inf. app. - inferior appendage. 


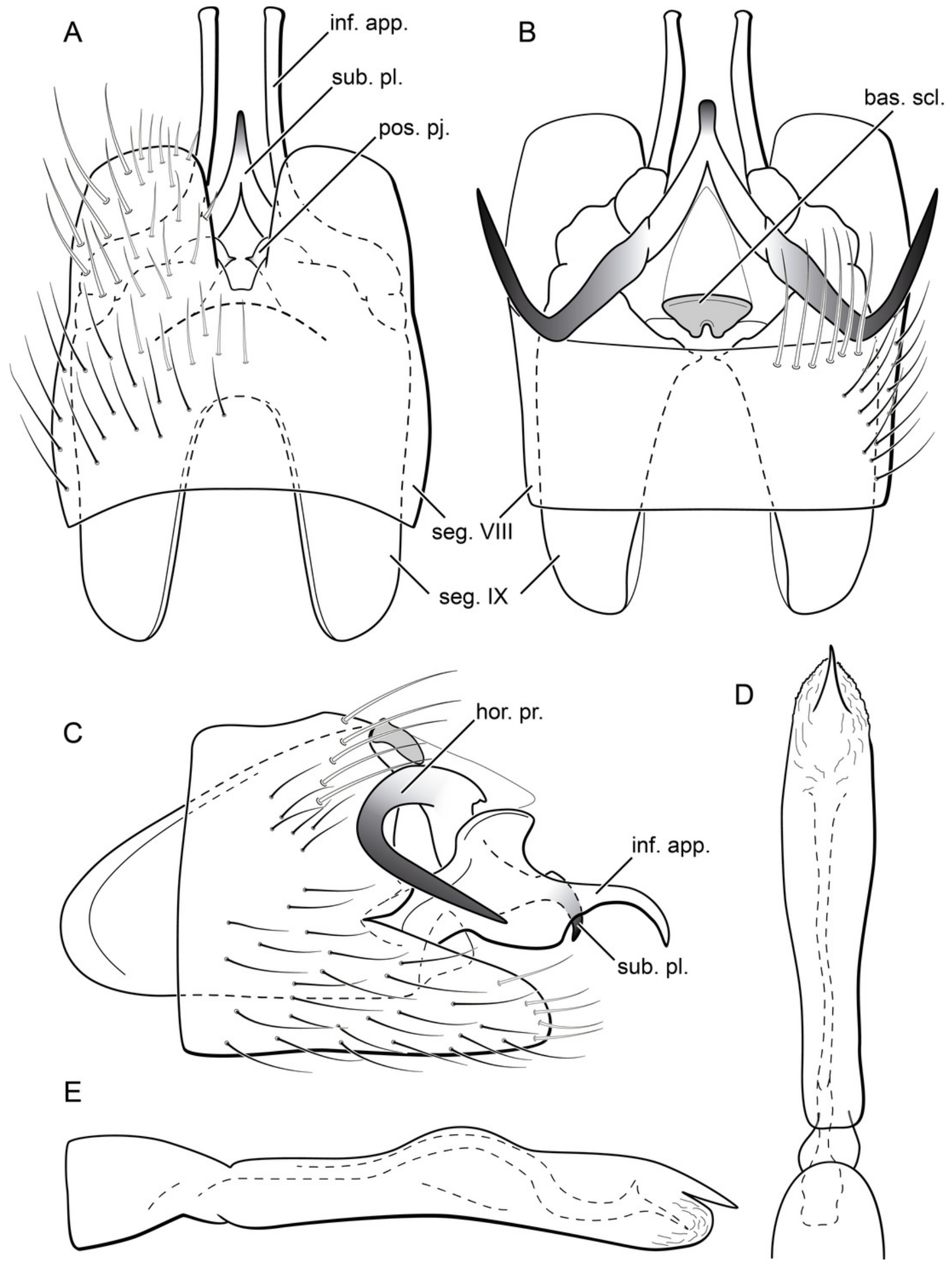

Peer] reviewing PDF | (2021:09:66094:1:1:NEW 22 Nov 2021) 


\section{Figure 14}

Byrsopteryx mancocapac sp. nov., larva.

Byrsopteryx mancocapac sp. nov., larva. (A) Lateral habitus with case. (B) Lateral habitus without case. (C) Dorsal habitus. (D) Operculum, dorsocaudal view.

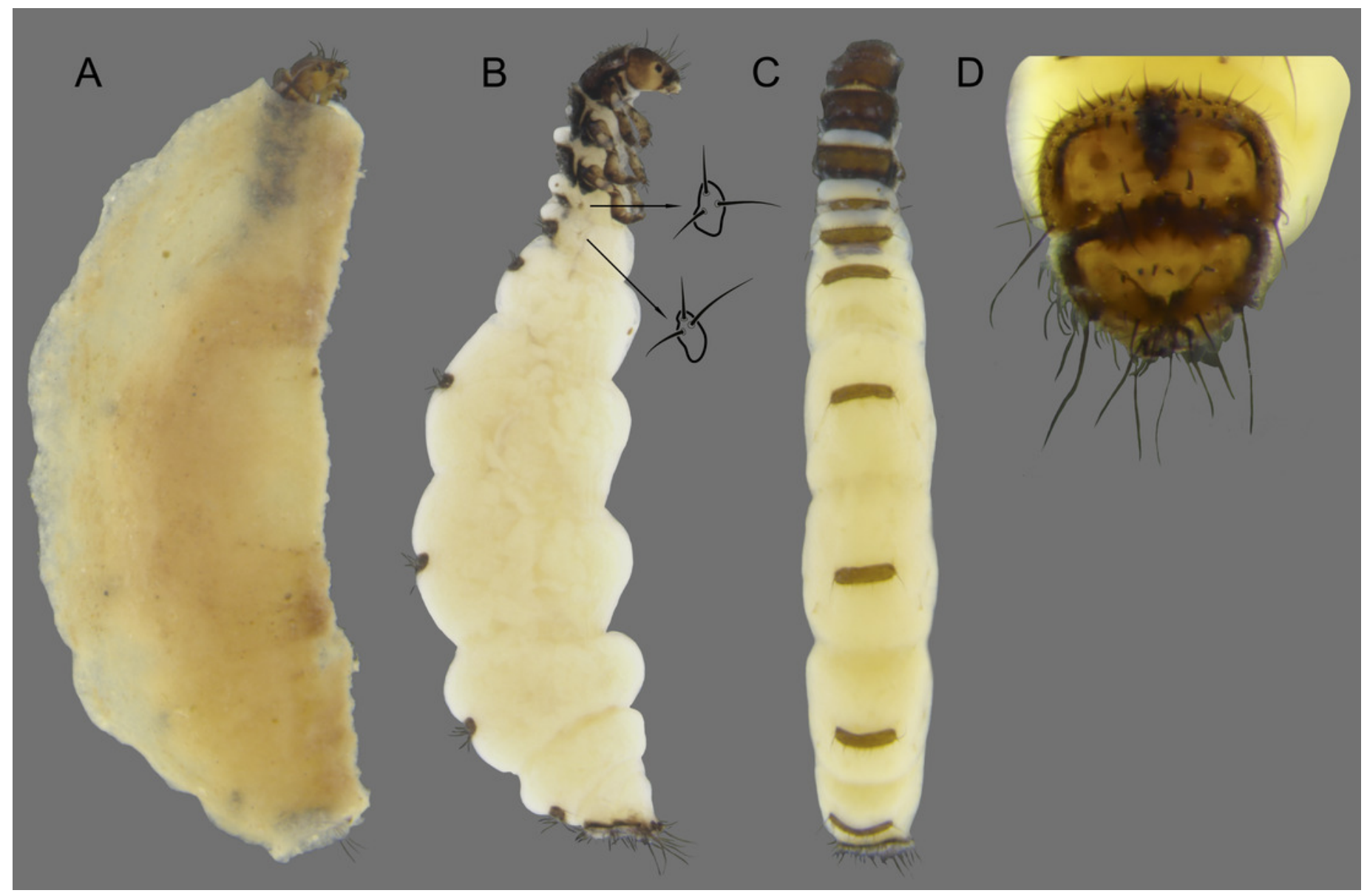

